\title{
Study of epoxy composites and sisal fibers as reinforcement of reinforced concrete structure
}

\section{Estudo da viabilidade da utilização de compósitos epóxi e fibras de sisal como reforço de estruturas de concreto armado}

H. M. FRANCKLIN a henriquefrancklin@gmail.com https://orcid.org/0000-0002-1416-7800

L. A. C. MOTTA a

lacastromotta@gmail.com https://orcid.org/0000-0002-1597-2297

J. CUNHA a

jecunha@ufu.br https://orcid.org/0000-0001-5981-1906

A. C. SANTOS a acds.pir@gmail.com https://orcid.org/0000-0001-9019-4571

M. V. LANDIM a mateusvazlandim@gmail.com https://orcid.org/0000-0002-4801-6699

\begin{abstract}
The application of structural reinforcement has presented a significant growth in the present days. The development of new materials for this purpose has aroused the interest of many researchers. The present work aim evaluate the production and application of polymers reinforced with vegetable fibers (PRFVeg) for reinforcement of reinforced concrete structures. An experimental program was developed using composites with $50 \%, 60 \%$ and $70 \%$ fibers volume content. The composites's tensile mechanical properties were evaluated in order to choose the fiber content with better mechanical performance. Epoxy matrix and sisal fibers were adopted in the production of PRFVeg. The reinforcement design was performed by numerical simulation using the finite element method. The reinforced beams were submitted to a 3-point flexural test until rupture and the performance of the material produced was compared to carbon fiber reinforced epoxy (PRFC) composites commonly used as reinforcement of reinforced concrete structures. The results obtained showed that the PRFVeg present similar performance compared to composites reinforced with carbon fibers, obtaining a load increase of up to $62 \%$ compared to the beams without polymer reinforcement.
\end{abstract}

Keywords: structural reinforcement, polymers reinforced with carbon fibers, polymers reinforced with sisal fibres.

\section{Resumo}

A aplicação de reforço estrutural tem apresentado crescimento significativo nos dias atuais. O desenvolvimento de novos materiais para tal finalidade tem despertado o interesse de muitos pesquisadores. O presente trabalho teve por objetivo avaliar a viabilidade técnica da produção e aplicação de polímeros reforçados com fibras vegetais (PRFVeg) para reforço de estruturas de concreto armado. Desenvolveu-se um programa experimental onde compósitos com teores de aproximadamente $50 \%, 60 \%$ e $70 \%$ em volume de fibras foram produzidos. As propriedades mecânicas à tração foram determinadas para avaliar o teor de fibras com melhor desempenho mecânico. Matriz epóxi e fibras vegetais de sisal foram adotadas na produção dos PRFVeg. O dimensionamento do reforço foi realizado mediante simulação numérica, utilizando o método dos elementos finitos. As vigas reforçadas foram submetidas a ensaio de flexão, em 3 pontos, até a ruptura e o desempenho mecânico do material produzido foi comparado com compósitos de matriz epóxi reforçada com fibras de carbono (PRFC), usados no mercado como reforço de estruturas de concreto armado. Os resultados obtidos mostraram que os PRFVeg apresentam desempenho similar aos já consagrados compósitos com fibras de carbono, obtendo incremento de carga de até $62 \%$, em relação as vigas sem reforço.

Palavras-chave: reforço estrutural, polímeros reforçados com fibras de carbono, polímeros reforçados com fibras de sisal. 


\section{Introduction}

The civil engineering industry has as a challenge to renovate the infrastructures meeting great economic restrictions. Some great effort from the scientific community was observed in the material development and methodologies to such purpose. From the environmental and economic point of view, it is preferable to rehabilitate a structure than demolishing and rebuilding it, especially constructions that are part of the historical heritage. The use of structural reinforcement became a promising way to increase the load capacity of the structures and extend their service life.

There was a number of factors related to the need of reinforcing the reinforced concrete structures, errors may be mentioned in the project and execution phases, aggressive environments and changes in the application load [2]. The structural reinforcement may be adopted to restore and increase the resistant capacity of the structures. The use of techniques based on the gluing of polymer composites reinforced with fibers (CFRP) in the reinforcement of reinforced concrete structures has attracted the attention of many researchers, mainly due to its advantages, among them the great relationship strength/weight of the materials, resistance to corrosion, facility and quickness in the application [3 and 4]. The researches were directed to the development of materials with high mechanical properties, light, simple and which cause few effects in architecture.

The carbon fiber reinforced polymers (CFRP) are considered the most modern and the appropriate alternative to the reinforcement of reinforced concrete beams, mainly for presenting great mechanical performance, resistance to corrosion, lightness, high tensile strength and high stiffness [5]. The high cost of the material can be balanced by the gain in the execution time, in the workforce cost and in the time decrease of the service interruption of the structure during the recovery work [6]. However, despite the advantages and good results reported, researches point that in most part of the cases the rupture of the reinforced elements is premature [7]. This kind of ruin is extremely undesirable since it occurs without warn-

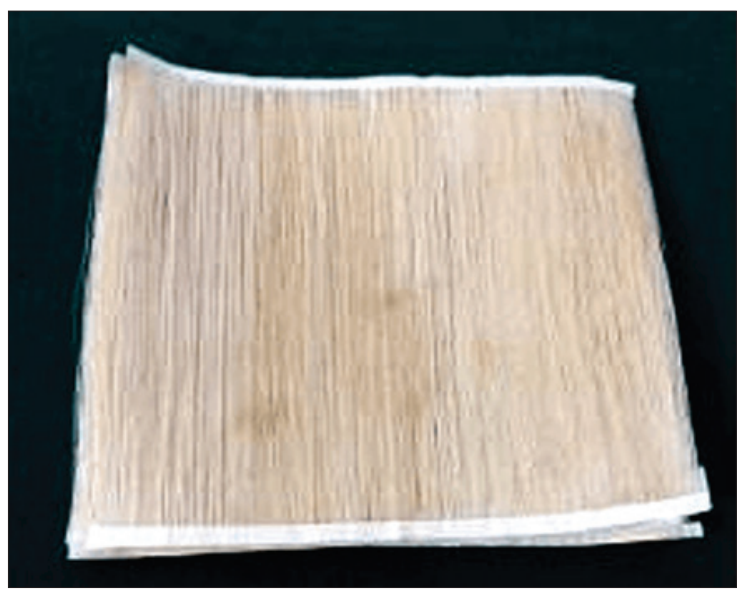

a) Sisal fiber ing and anticipates the collapse of the reinforced beam, making impossible the full utilization of high composites strength with carbon fibers in the system [4, 7].

The premature failures in reinforced beams with FRP occur mainly due to interface high tensions, being themselves normal or shearing. Recent studies showed that premature failures due to unsticking may be minimized when the anchorage is efficient and carefully projected $[8,9]$. Significant strength increments may be reached only if the premature ruin modes are avoided.

Recent papers suggest the use of new fiber-matrix combinations to CFRP development with application in structural reinforcement, in order to reduce the high costs of reinforcement systems commonly used. In recent years, the use of composite materials reinforced with natural fibers has considerably increased in the civil industry section [10]. Properties from these composites may be adapted to many types of applications, from the fiber choice, using different matrices and additives, and performing fiber treatments [11].

The search for alternative materials which enable the substitution of synthetic fibers to natural fibers present social and economic advantages, reducing costs, environmental impact and energy consumption [12]. Vegetable fibers present themselves as a sustainable alternative, which enable the economy development from isolated regions, representing an important source of income to local populations [13].

The performance of composites of vegetable fibers is directly related to the content of cellulose and decrease of the spiral angle related to the fiber axis [14], type of matrix, geometry and fibers guidance [15]. The usage of thermoplastic and thermoset matrices in the development of the composites reinforced by natural fibers has considerably increased in recent years [10].

Sisal fiber is a vegetable fiber from cellulose withdrawn from the leaves of Agave sisalana plant, native from Mexico [16]. Brazil is one of the greatest producers of the plant and it cultivates those fibers in Northeast hinterlands in semi-arid regions, for the facility of the plant to adapt itself to dry regions [17]. Sisal fibers present adequate mechanical properties to the production of CFRP with application in civil industry $[18,19]$. Its usage in the production of

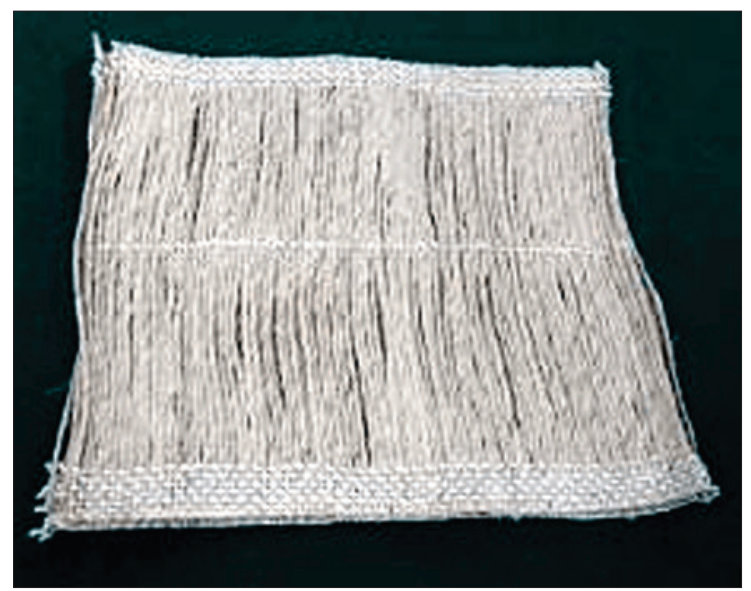

b) Sisal fabric

Figure 1

Fibers and sisal fabrics 
Table 1

Mass of resin and sisal fabrics

\begin{tabular}{ccc}
\hline $\begin{array}{c}\text { Content of fibers } \\
\text { in volume } \\
(\%)\end{array}$ & $\begin{array}{c}\text { Mass of fiber } \\
(\mathrm{g})\end{array}$ & $\begin{array}{c}\text { Mass of resin } \\
(\mathrm{g})\end{array}$ \\
\hline $50 \%$ & 90.60 & 68.96 \\
$60 \%$ & 108.72 & 55.17 \\
$70 \%$ & 126.84 & 41.37 \\
\hline
\end{tabular}

the composites with thermoplastic matrices $[20,21]$ and thermoset $[22,23]$ was extensively studied. This study aims to produce and characterize composites of epoxy resin reinforced with fibers and sisal fabric in high contents and to investigate its application in the reinforcement to the bending of reinforced concrete beams.

\section{Experimental design/program}

The experimental program was divided in two phases. First, composites with contents of approximately $50 \%, 60 \%$ and $70 \%$ of vegetable fibers were produced. After the production, a characterization of their mechanical properties was performed and those with better results were selected to further application as a reinforcement of reinforced concrete beams. In parallel to the experimental program, numerical simulations were performed, using the Finite Element Method, in order to dimension the vegetable reinforcement in the beam to reach similar performance to CFRP. In the second phase, reinforced concrete beams were produced and reinforced with composites produced in studies and carbon laminates, to evaluation and comparison to the bending performance.

\subsection{Materials to the production of vegetable composites: Phase -1}

The composites were produced with matrix to epoxy resin and to the reinforcement fibers and fabrics with sisal yarns were analyzed. Fibers and yarns were distributed in the composites in a continuous and aligned way in only one direction (Figure 1), since the alignment of fibers/yarns in the direction of active efforts in the composites optimizes their mechanical performance.

The fabrics were produced with twisted yarns, where the warps were manufactured with cotton yarns and wefts with sisal yarns with diameter of $2 \mathrm{~mm}$ (Figure 1b). Various layers were produced with fibers and sisal fabrics so that each layer was overlaid until they reached the mass of fibers/fabrics necessary to the content of each composite. The specific mass of fibers was determined by Helium pycnometer, resulting in $1,511 \mathrm{~g} / \mathrm{cm}^{3}$.

Epoxy resin was selected by presenting excellent mechanical properties, good compatibility, and little contraction during its cure and adherence with vegetable fibers, in addition to establish comparative basis with carbon fibers with the same matrix. Resin is constituted by a resulting system from the reaction of epichlorohydrin with bisphenol A, modified with aliphatic reactive extensors and the stiffener based on modified polyamine, produced by Silaex $®$ Química Ltda. The proportion of the adopted mixture, between resin and stiffener, was of 100:15 parts in mass, in order to guarantee time to work sufficient to the preparation of the composed. The specific mass of resin with this proportion resulted in $1,15 \mathrm{~g} /$ $\mathrm{cm}^{3}$ [25]. Table 1 presents the compositions of the composites, with different contents of fibers.

\subsection{Production and test of vegetable composites}

The fibers/fabrics were dried in ovens, in in a temperature of $60 \pm 5^{\circ} \mathrm{C}$, for 24 hours. The composites were prepared by compression in environment temperature $\left(25^{\circ} \mathrm{C} \pm 5^{\circ} \mathrm{C}\right)$, using metal molds with internal dimensions of $19,5 \mathrm{~cm} \times 20,5 \mathrm{~cm} \times 2,5 \mathrm{~cm}$, and a hydraulic vise.

Part of the homogenous mixture of resin and stiffener was placed in the mold and later a fiber layer, performing the manual thickening. This procedure was repeated alternating in resin and fiber layers until it reached the composite content of fibers. When this phase was over, the mold was closed and put in the hydraulic vise and the necessary force was applied until the composite reach $3 \mathrm{~mm}$ thickness. The composite was left in the vise for 24 hours and the healing process lasted 48 hours (Figure 2).

After the unmolding, 9 test specimens were cut, in the fibers orientation direction, in a ROUTER laser machine. The samples were cut in the dimensions recommended by ASTM D638:2012 [26]. Figures 3 and 4 have presented the composites produced for tensile tests.

The samples were submitted to tension test, in a Universal Testing Machine, Instron, model 5982, with load cell of $100 \mathrm{kN}$, following ASTM D3039:2014 [27] recommendations. The tension force was
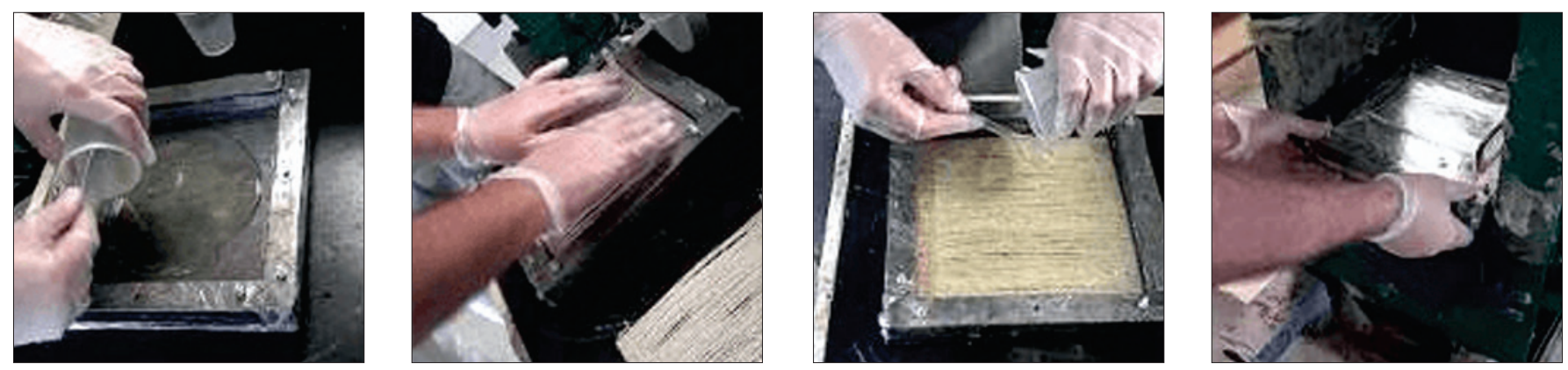

Figure 2

Stages of the preparation of the composites 


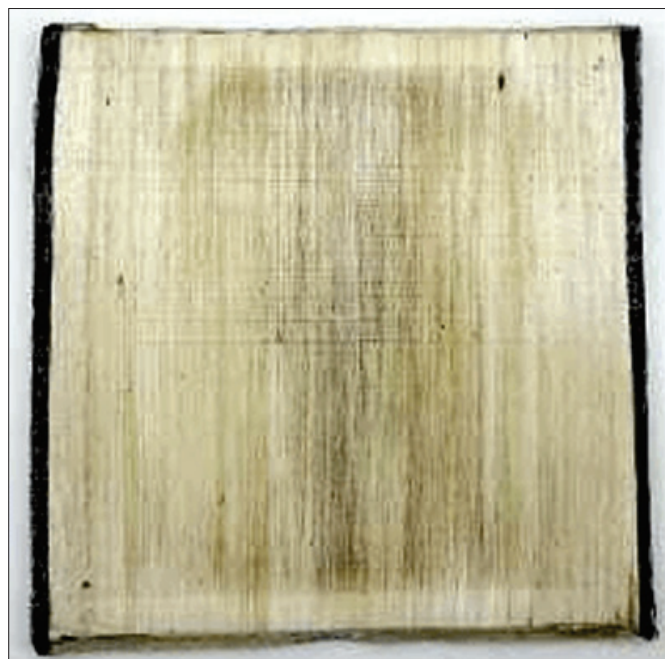

a) Molded plate

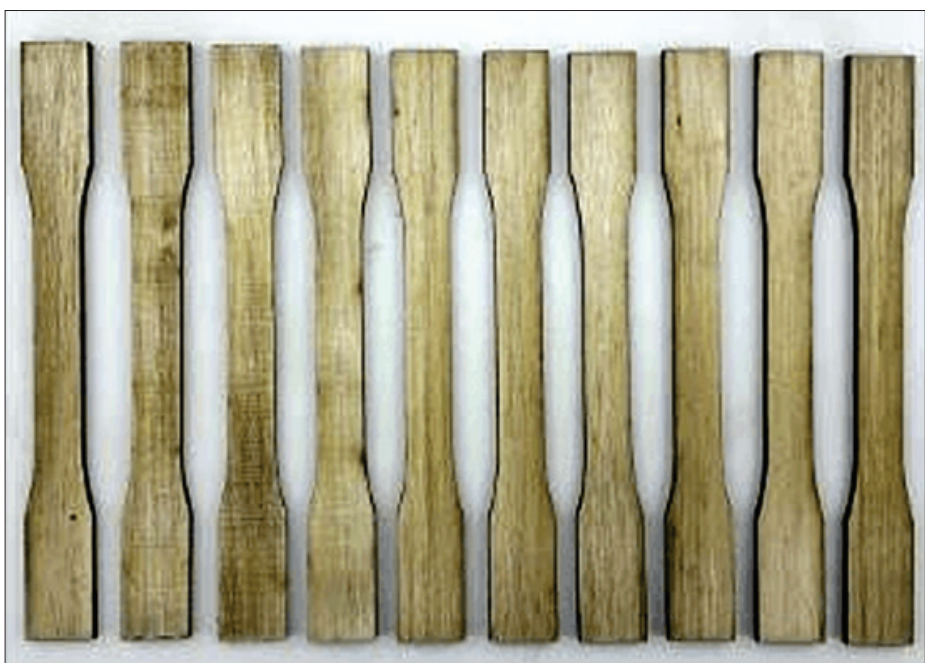

b) Test specimens

Figure 3

Composite of epoxy resin reinforced with sisal fibers

applied with $2 \mathrm{~mm} / \mathrm{min}$ speed until the composite rupture. To the deformation measurement, an Instron extensometer was used, with capacity of maximum elongation of $25 \mathrm{~mm}$. From the tension test there was obtained: modulus of elasticity, tensile strength and maximum deformation in the rupture of every composite.

\subsection{Tests of carbon composites}

To obtain elastic properties from carbon laminate, used as reinforcement, tensile tests were performed in test specimens following ASTM D3039:2014 [27] recommendations. Five sam- ples were prepared with $250 \mathrm{~mm}$ length and $15 \mathrm{~mm}$ width. To avoid damages to the test specimens in the region of the applied force by the claws of the test machine, tabs were glued in the end of the samples, manufactured with their own laminate, with $56 \mathrm{~mm}$ length. The samples were submitted to tensile test following the same procedures performed to the vegetable composites (Figure 5).

\subsection{Numerical simulation}

In order to pre-design the vegetable reinforcement to obtain

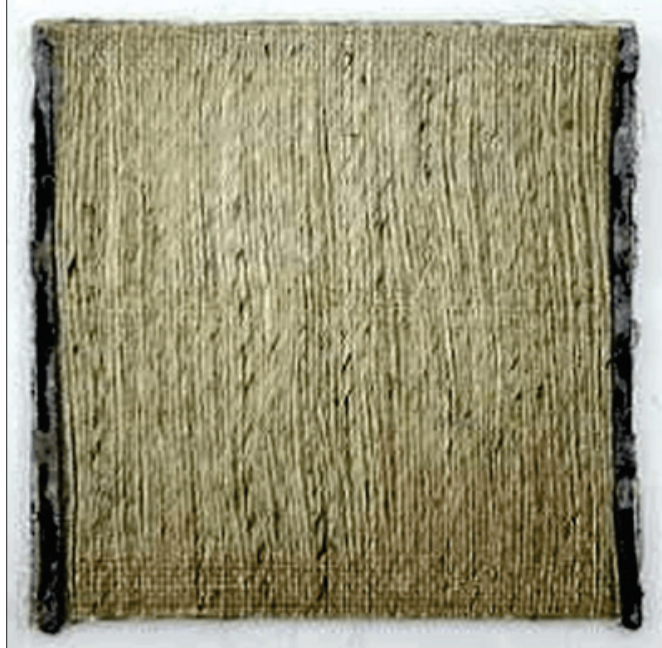

a) Molded plate

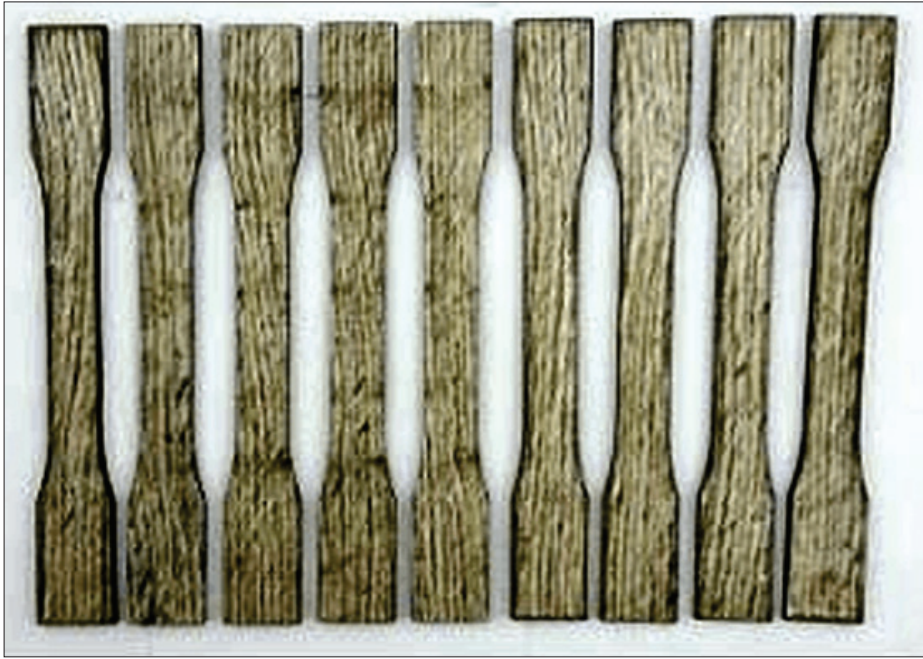

b) Test specimens

Figure 4

Composite of epoxy resin reinforced with sisal fabrics 


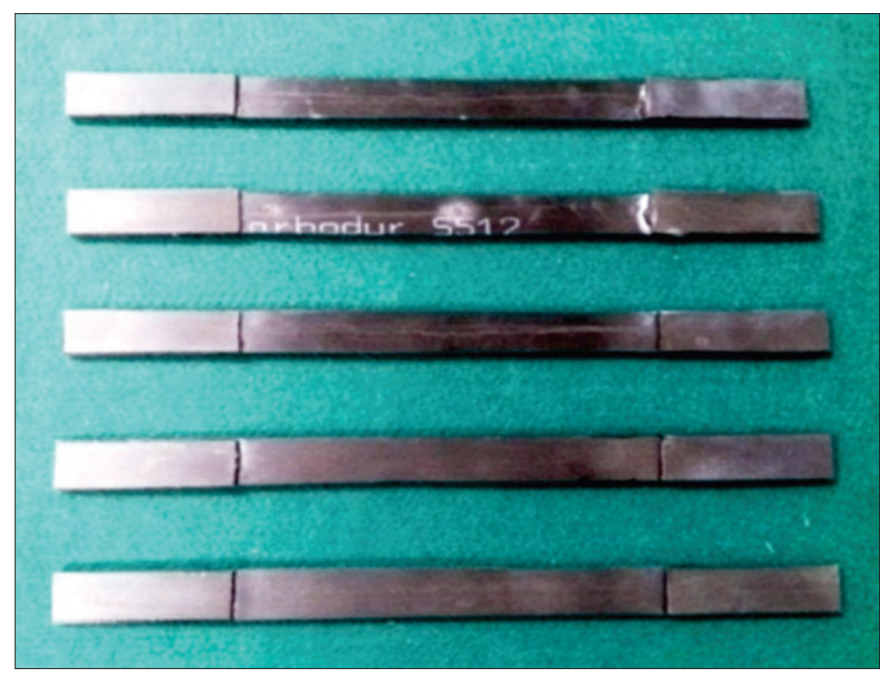

a) Test specimens

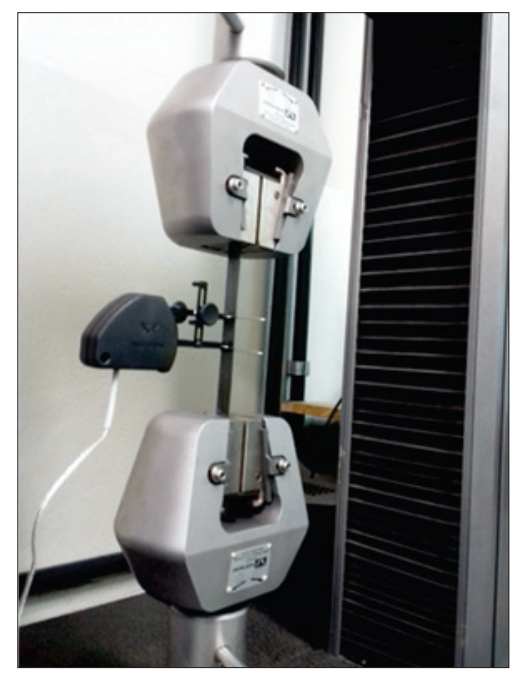

(b) Configuration of test

\section{Figure 5}

Tensile test from carbon composites

mechanical performance similar to CFRP reinforcement, a reinforced concrete beam was shaped, twice backed, with gaps between supports of $45 \mathrm{~cm}$ and reinforced with a CFRP layer. CFRP range was positioned in the middle of the bottom surface of the beam, region where all the normal tension stresses are bigger, being the reinforcement the form of a $5 \mathrm{~cm} \times 40$ c track. The model was submitted to a vertical load of $50 \mathrm{kN}$ distributed over the central cross section. In Figure 6 it is illustrated the reference beam to comparison with the beam reinforced with VegFRP.

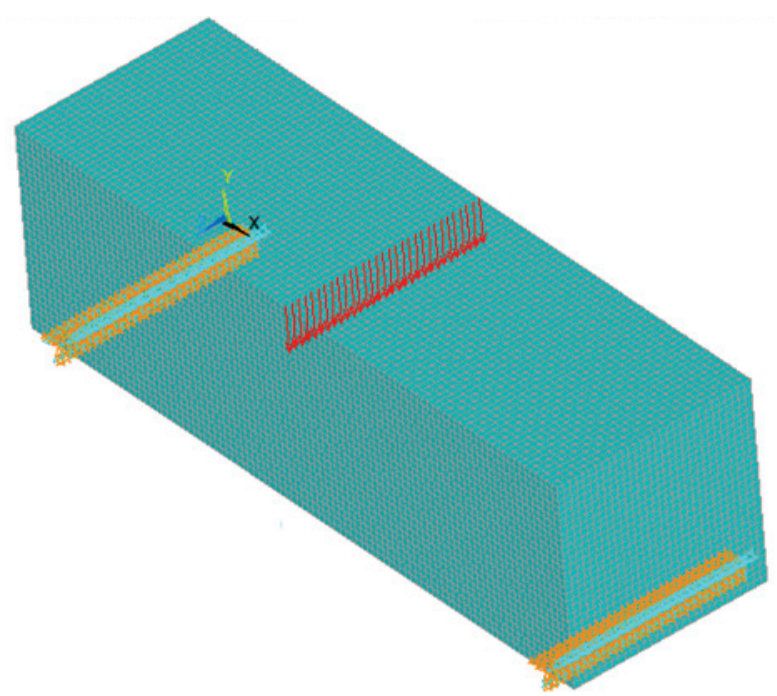

a) Condition of contour and load

\section{Figure 6}

Molding of bi-supported beam reinforced with CFRP
In modeling each reinforced beam element, an ANSYS ${ }^{\circ}$ biphasic tridimensional element was adopted, being the BEAM 188 element to the rebar and the SOLID 185 element to the concrete and reinforcement (CFRP and VegFRP). In Table 2 the properties used to modeling of the reinforced beam with CFRP are presented. In Figure 7 the distribution of tensions in the beam without effort and in the reinforced one with CFRP was presented. When the rupture load from the beam with CFRP reinforcement was obtained, the load was transferred to the reinforced numerical model with VegFRP, determining the necessary thickness to reach

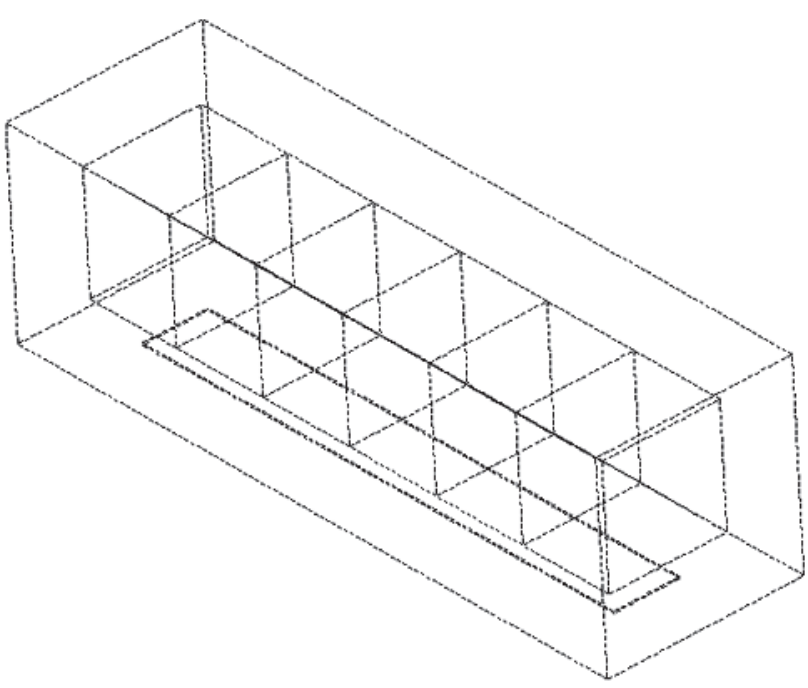

b) Details of the rebar and position of the reinforcement 


\section{Table 2}

Properties used in the modeling of the beam reinforced with CFRP

\begin{tabular}{|c|c|c|}
\hline Properties & Description & Value \\
\hline$\varnothing$ & Diameters of the bars & $5 \mathrm{~mm}$ \\
\hline$b_{w}$ & Width of the beam session & $15 \mathrm{~cm}$ \\
\hline h & Height of the beam session & $15 \mathrm{~cm}$ \\
\hline C & Length of the beam & $50 \mathrm{~cm}$ \\
\hline w & Width of CFRP track & $5 \mathrm{~cm}$ \\
\hline e & Thickness of the CFRP layers & $1.2 \mathrm{~mm}$ \\
\hline$E_{s}$ & Modulus of elasticity of steel & $21,000 \mathrm{kN} / \mathrm{cm}^{2}$ \\
\hline$E_{c o n}$ & $\begin{array}{l}\text { Modulus of elasticity } \\
\text { of concrete }\end{array}$ & $2,380 \mathrm{kN} / \mathrm{cm}^{2}$ \\
\hline$E_{f}$ & Modulus of elasticity of CFRP & $16,681.5 \mathrm{kN} / \mathrm{cm}^{2}$ \\
\hline$v_{s}$ & Poisson coefficient from steel & 0.3 \\
\hline$v_{c}$ & $\begin{array}{l}\text { Poisson coefficient from } \\
\text { concrete }\end{array}$ & 0.2 \\
\hline$v_{f}$ & $\begin{array}{c}\text { Poisson coefficient from } \\
\text { CFRP }\end{array}$ & 0.27 \\
\hline$f_{c k}$ & $\begin{array}{l}\text { Characteristic compressive } \\
\text { strength of concrete }\end{array}$ & $2.5 \mathrm{kN} / \mathrm{cm}^{2}$ \\
\hline
\end{tabular}

structural performance similar to CFRP. The necessary thickness from VegFRP obtained in the simulation was $5,5 \mathrm{~mm}$. The sisal composite adopted to reinforcement has $70 \%$ of fibers, which presented better properties to tensile, with $35,80 \mathrm{GPa}$ modulus of elasticity. The Possion's Coefficient adopted to VegFRP was the same used to the carbon laminate. In Table 3 the obtained results in the simulation of the bending of the beams without effort and with two types of studied reinforcements are presented.

\section{Table 3}

Results from different modeling from the reinforcement in the combat to bending moment

\begin{tabular}{cccc}
\cline { 2 - 4 } & $\begin{array}{c}\text { Reinforcement } \\
\text { thickness } \\
(\mathbf{c m})\end{array}$ & \multicolumn{2}{c}{$\begin{array}{c}\text { Tensile } \\
\left(\mathrm{kN} / \mathrm{cm}^{2}\right)\end{array}$} \\
\hline $\begin{array}{c}\text { Without } \\
\text { reinforcement }\end{array}$ & - & $\begin{array}{c}\text { Top } \\
\text { Bottom }\end{array}$ & 0.84247 \\
0.91684 \\
\hline With reinforcement & 0.127 & Top & 0.81957 \\
$-68 \%$ carbon fibers & Bottom & 0.83921 \\
\hline $\begin{array}{c}\text { With reinforcement } \\
-70 \% \text { sisal fibers }\end{array}$ & 0.55 & Top & 0.81945 \\
& & Bottom & 0.83977 \\
\hline
\end{tabular}

\subsection{Performance evaluation of composites as reinforcement: Phase - 2}

This phase of the study had the aim of evaluating the performance of composites as structural reinforcement, by the increment values of load capacity of the beams, when subjected to bending. For this purpose, 13 reinforced concrete beams were produced in $15 \mathrm{~cm}$ $x 50 \mathrm{~cm}$ dimensions divided in 3 groups. The so-called "control" groups, which are the beams without reinforcement, RC group, which are the reinforced beams with CFRP and RS group, which are the beams reinforced with VegFRP with better mechanical performance found in phase 1 from this study (Table 4).

The beams were designed so that they had bending rupture with excessive plastic deformation of the rebar. 5,0 mm diameter bars were adopted to longitudinal rebar, corresponding to a rate of $0,17 \%$. The transversal rebar was constituted by steel bars of 5,00 $\mathrm{mm}$ diameter, spaced in each

\section{Table 4}

Description of testes groups in the second phase of the study

\begin{tabular}{ccccc}
\hline \multirow{2}{*}{ Group } & CP (Beam) & Reinforcement & \multicolumn{2}{c}{ Dimensions of the beams } \\
\cline { 2 - 5 } Control & 1,2 and 3 & Without reinforcement & $\mathbf{b}(\mathbf{c m})$ & $1(\mathbf{c m})$ \\
RC & $4,5,6,7$ and 8 & Carbon & 15 & 15 \\
RS & $9,10,11,12$ and 13 & Sisal & & 15 \\
\hline
\end{tabular}

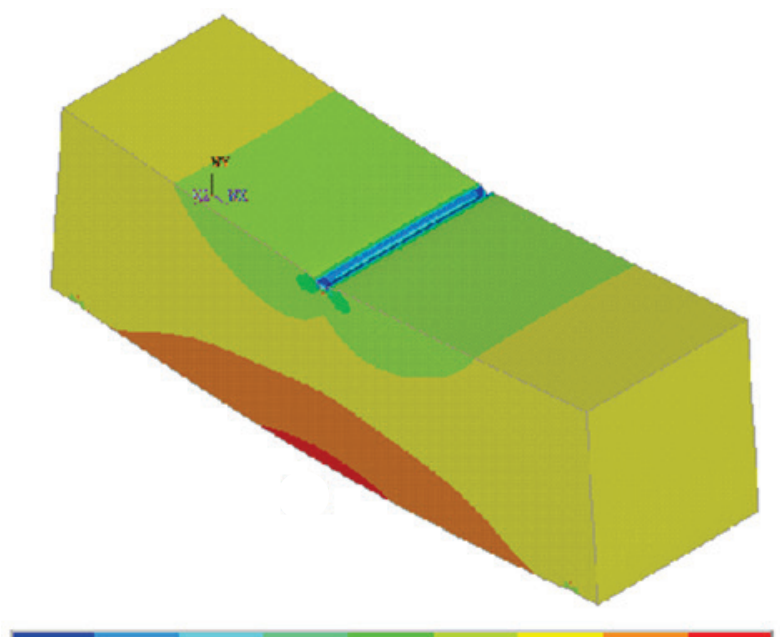

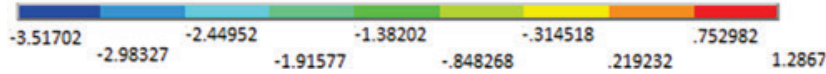

(a)

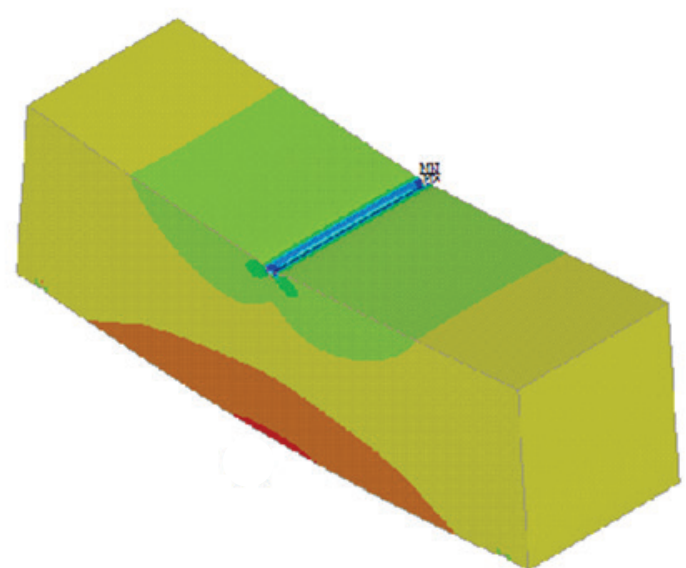

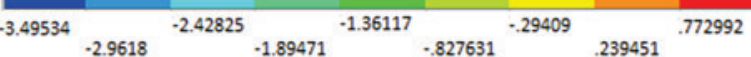

(b)

Figure 7

Normal tensile before (a) and after (b) the reinforcement gluing $\left(\mathrm{kN} / \mathrm{cm}^{2}\right)$ 


\section{Table 5}

Results from the tensile tests of the steel bars used in the beams' rebar

\begin{tabular}{ccc}
\hline $\begin{array}{c}\text { Diameter } \\
(\mathrm{mm})\end{array}$ & $\begin{array}{c}\text { Tensile of average } \\
\text { drainage }\left(F_{\mathrm{y}}\right) \\
(\mathrm{MPa})\end{array}$ & $\begin{array}{c}\text { Tensile of average } \\
\text { disruption }\left(\mathrm{F}_{\mathrm{r}}\right) \\
(\mathrm{MPa})\end{array}$ \\
\hline 5 & 788.57 & 828.63 \\
& $(86.09)$ & $(89.41)$ \\
\hline
\end{tabular}

\section{Table 6}

Results of the tensile tests to compression and modulus of elasticity of concrete

\begin{tabular}{ccc}
\hline $\begin{array}{c}\text { Age } \\
\text { (days) }\end{array}$ & $\begin{array}{c}\text { Tensile to average } \\
\text { compression } \\
(\mathrm{MPa})\end{array}$ & $\begin{array}{c}\text { Modulus of } \\
\text { elasticity - average } \\
\text { (GPa) }\end{array}$ \\
\hline 7 & 27.8 & 32.12 \\
& $(2.29)$ & $(5.85)$ \\
144 & 48.01 & 44.98 \\
& $(4.09)$ & $(1.71)$ \\
\hline
\end{tabular}

$7,30 \mathrm{~cm}$, being dimensioned to avoid beam rupture by shearing. Tensile tests in the steel bars used in the beams were done, obeying ABNT NBR 7480:2007 [28] specifications. The obtained results are indicated in Table 5 , and Figure 8 presents the beam's rebar in detail.

Concrete production was done in laboratory, mixing the materials mechanically in a concrete mixer, with capacity of 320 liters. The trace used was to obtain compression strength of $25 \mathrm{MPa}$ to 28 days, having as proportion in 1:2,3:3:0,48 dry mass and cement consumption of $367 \mathrm{Kg} / \mathrm{m}^{3}$. It was used $0,8 \%$ (related to cement mass) of superplastificizer addictive to obtain rebate of $170 \mathrm{~mm}$.

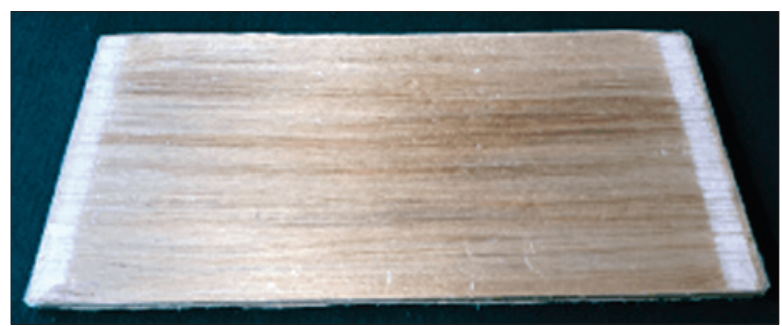

a) Molded plate

Figure 9

Polymers reinforced with 70\% sisal fibers (SFRP)

Table 7

Composition of the materials from vegetable reinforcement

\begin{tabular}{cccccccc}
\hline Plate & $\begin{array}{c}\text { Thickness } \\
(\mathbf{c m})\end{array}$ & $\begin{array}{c}\text { Volume } \\
\left(\mathbf{c m}^{3}\right)\end{array}$ & $\begin{array}{c}\text { Composite } \\
\text { mass } \\
(\mathbf{g})\end{array}$ & $\begin{array}{c}\text { Dry fiber mass } \\
(\mathbf{g})\end{array}$ & $\begin{array}{c}\text { Resin mass } \\
(\mathrm{g})\end{array}$ & $\begin{array}{c}\text { Specific mass } \\
\left(\mathbf{g} / \mathrm{cm}^{3}\right)\end{array}$ & $\begin{array}{c}\text { Final content } \\
\text { of fibers } \\
\text { in volume } \\
(\%)\end{array}$ \\
\hline 01 & 0.56 & 478.19 & 702.70 & 531.60 & 171.10 & 1.47 & $74 \%$ \\
02 & 0.57 & 479.61 & 707.20 & 529.48 & 177.72 & 1.47 & $73 \%$ \\
\hline
\end{tabular}

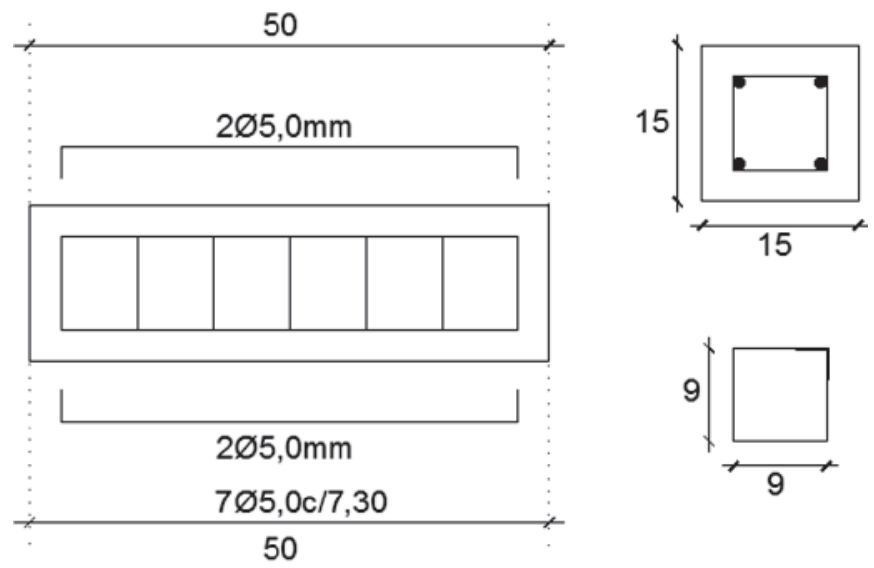

Figure 8

Detail of the beams' rebar

Besides the beams, cylindrical test specimens were molded, with $10 \mathrm{~cm}$ $x 20 \mathrm{~cm}$ dimensions, to the characterization of the compression strength (NBR 5739:2007 [29]) and concrete modulus of elasticity (ABNT NBR $8522: 2008$ [30]), tests in the ages of 28 days and on the date of the beams tests. Table 6 presents the obtained results in the concrete tests. Vegetable reinforcement was produced in the same methodology described in item 2.2, to the content of $70 \%$ of sisal fibers. The molded plate presented approximately $21,0 \mathrm{~cm}$ width and $40,5 \mathrm{~cm}$ length and later it was cut into four test specimens with dimensions of 5 $\mathrm{cm} \times 40 \mathrm{~cm}$. The composite thickness was determined according to numerical simulations, as explained in item 2.4 , adopting a thickness of approximately $0,55 \mathrm{~cm}$. Table 7 presents the composition of

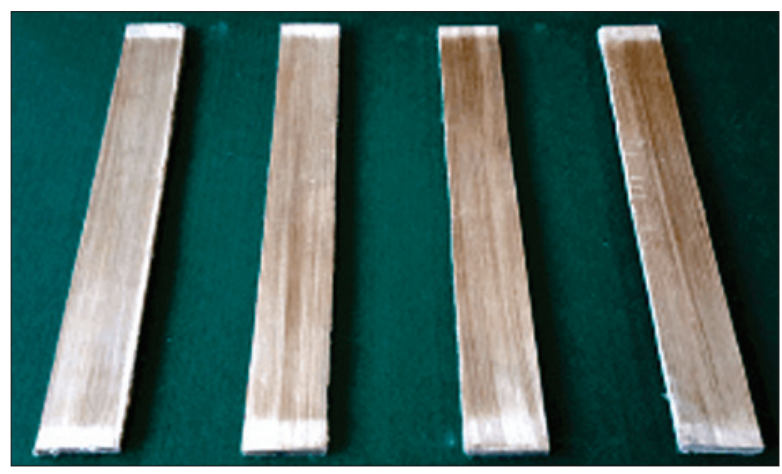

b) Reinforcement ready to gluing on the beams 
materials used in the production of vegetal reinforcement and Figure 9 presents the molded plate and the composites ready for gluing on the beams.

\section{Table 8}

Physical and mechanical properties from the carbon laminate provided by the manufacturer

\begin{tabular}{cc}
\hline Properties & Values \\
\hline Base & Carbon fibers in epoxy matrix \\
Color & Black \\
Content of fibers in volume & $>68 \%$ \\
Density & $1.6 \mathrm{~g} / \mathrm{cm}^{3}$ \\
Resistance to temperature & $>100^{\circ} \mathrm{C}$ \\
Width & $50 \mathrm{~mm}$ \\
Thickness & $1.2 \mathrm{~mm}$ \\
Transverse section & $60 \mathrm{~mm}$ \\
Modulus of elasticity & $165,000 \mathrm{MPa}$ \\
Tensile strength & $2,400 \mathrm{MPa}$ \\
Tensile strength in disruption & $3,100 \mathrm{MPa}$ \\
Deformation & $>1.7 \%$ \\
\hline
\end{tabular}

\section{Table 9}

Properties of strength to average compression of epoxy adhesive

\begin{tabular}{cc}
\hline $\begin{array}{c}\text { Age } \\
\text { (days) }\end{array}$ & $\begin{array}{c}\text { Strength to average } \\
\text { compression } \\
\text { (MPa) }\end{array}$ \\
\hline 7 & 61.48 \\
$(10.42)$ \\
\hline
\end{tabular}

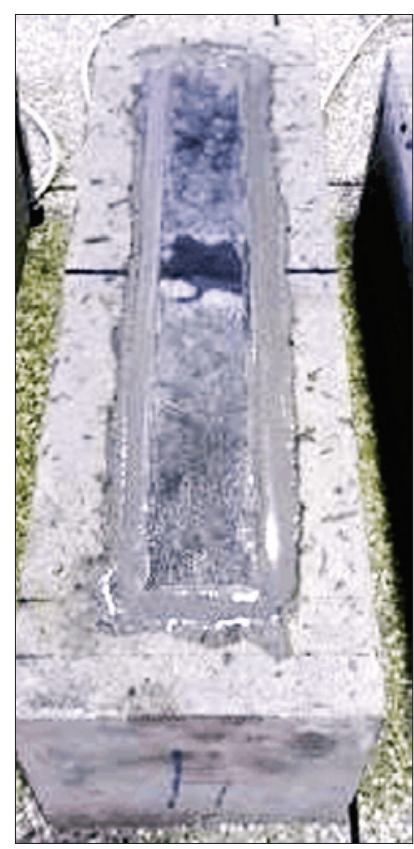

a) CFRP

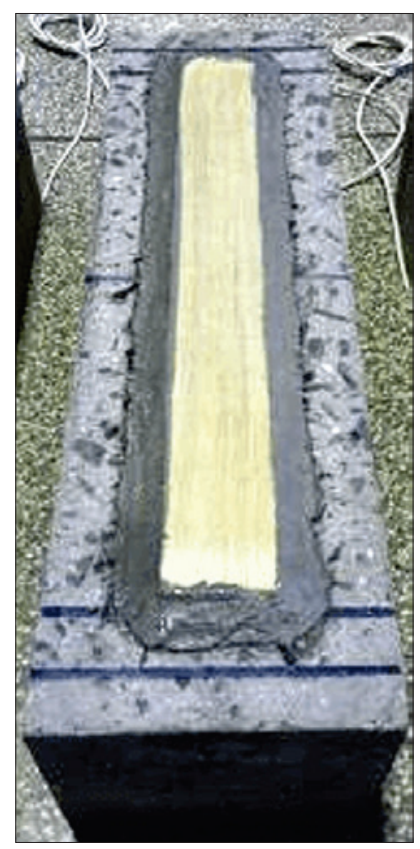

b) SFRP
Figure 10

Reinforcements glued on the beams
Carbon reinforcement was Sika ${ }^{\circledR}$ CarboDur ${ }^{\circledR}$ S 512 type. The laminate is unindirectionally reinforced with carbon fibers, presenting 1,2 $\mathrm{mm}$ thickness and $50 \mathrm{~mm}$ width. The same ones were cut with $40 \mathrm{~cm}$ length and later cleaned with acetone, so that the application in the beams would be done. Table 8 presents the physical and mechanical properties of CFRP.

To the gluing of reinforcement in the beams, the concrete surface was prepared with the withdrawal of the most external layer, with the use of electrical grinder, until the full-grown households were exposed and all the extension of the beam was leveled.

After that, reinforcement in the beams was applied, using an adhesive based on epoxy resin, mixed in the proportion of three parts of the epoxy formulation to one part of catalytic. Figure 10 presents reinforced beams. To verify the mechanical properties of epoxy adhesive, compression tests were performed in three cylindrical test specimens, with $5 \mathrm{~cm} \times 10 \mathrm{~cm}$ dimensions, to the age of 7 days. Table 9 presents the obtained results to the epoxy adhesive tests.

The bending tests were done following the recommendation described

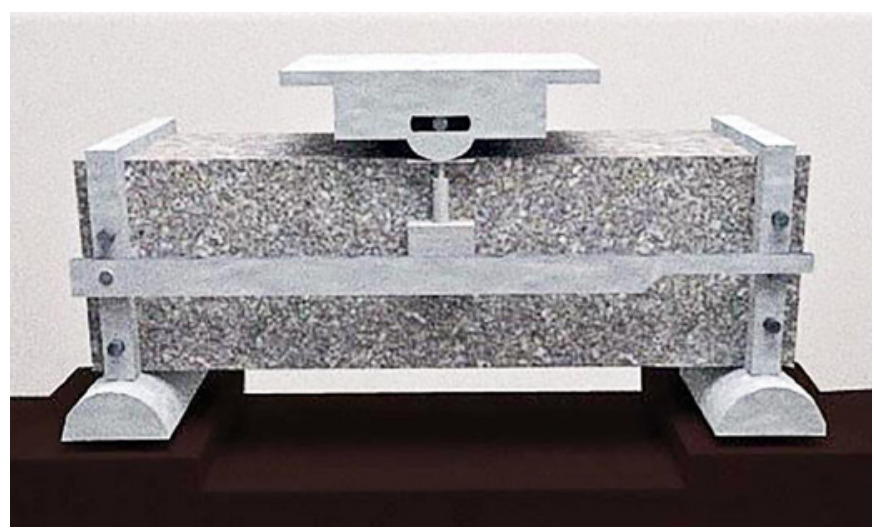

Figure 11

Scheme of bending test from the beams

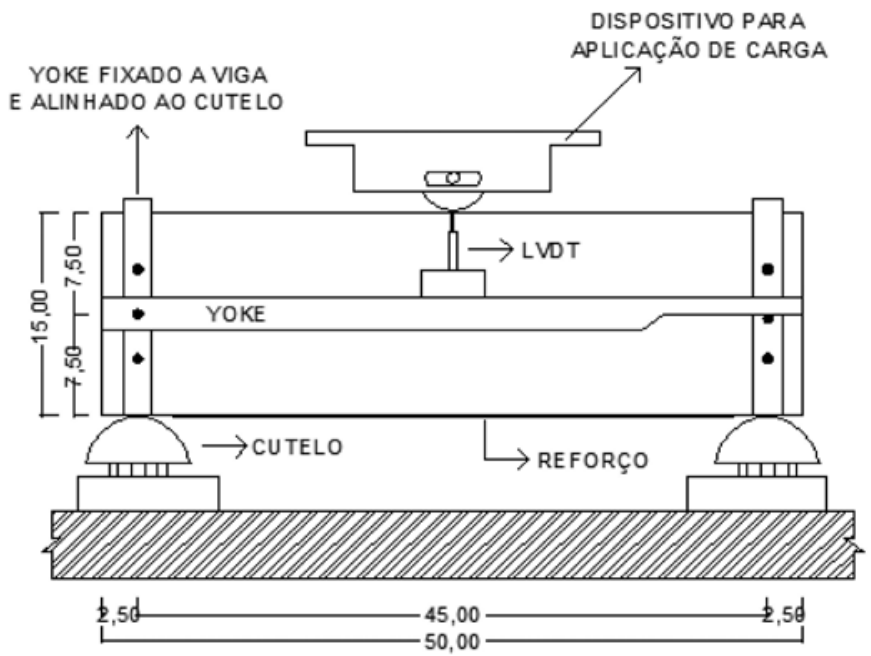

Figure 12

Schematic representation of "YOKE" device in the beam 
by ABNT NBR 12142:2010 [31], being three-point bending type. Application of the force was gradual and uniform, avoiding shocks, in a way that the increase of the tension on the beam was understood in $0,9 \mathrm{MPa} / \mathrm{min}$ to $1,2 \mathrm{MPa} / \mathrm{min}$ interval. The test pattern is represented in Figure 11 .

With the purpose of a better comprehension of the structural element behavior under analysis, electrical extensometers were glued to the tensioned longitudinal rebar, in the central region, in order to measure the deformations of the rebar. LVDT (Linear Variable Differential Transformer) type transducers were also used to measure the displacement in the middle of the beam span. To position LVDT in the beam, YOKE system was applied. This device is characterized by being a template, constituted by a group of pins and metallic plates. The holders of YOKE device were put on the choppers, so that there was not rotation. LDVT was fixed on YOKE device, positioned in the average height of every lateral face of the beam, so that the same one could measure its displacements in the middle of the span, not having restrictions. Figure 12 shows the schematic representation of the details from YOKE device holders. During tests performances, the data capture of strength was registered by data acquisition system from Instron itself, with load cells of $100 \mathrm{kN}$, and to the deflection monitoring and rebar specific deformations, the data were registered by an acquisition system using a HBM equipment connected to the laptop.

\section{Results and discussions}

\subsection{Analysis from vegetable composites results - Phase - 1}

With the rise of fiber contents in the matrix, it was observed an

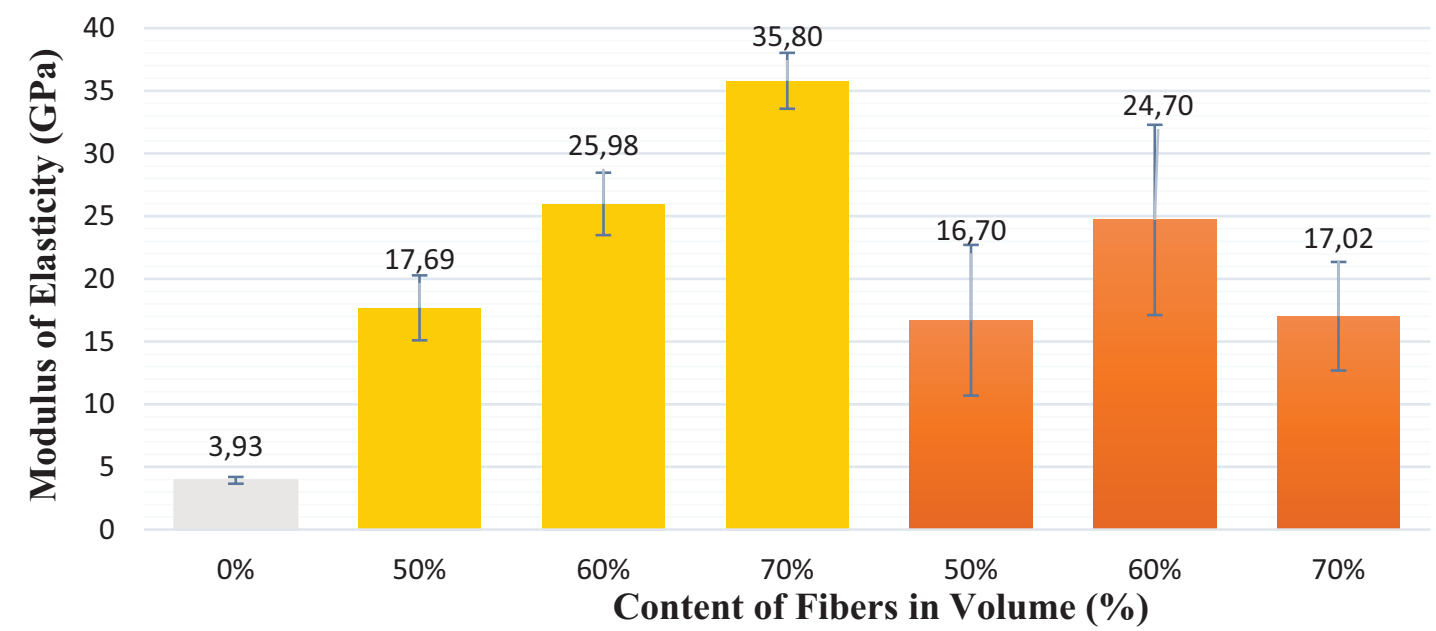

\section{Figure 13}

Modulus of elasticity from composites with sisal fibers and yarns

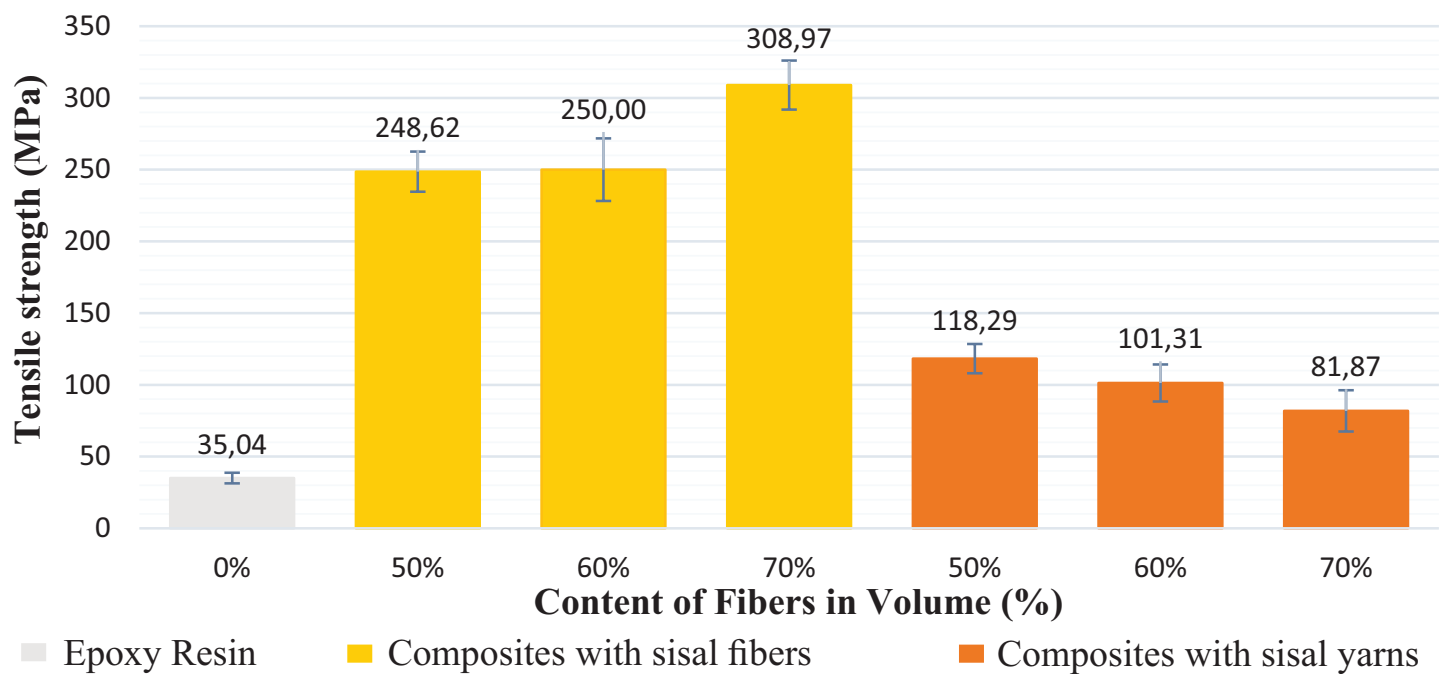

Figure 14

Tensile strength from composites with sisal fibers and yarns 
Study of epoxy composites and sisal fibers as reinforcement of reinforced concrete structure

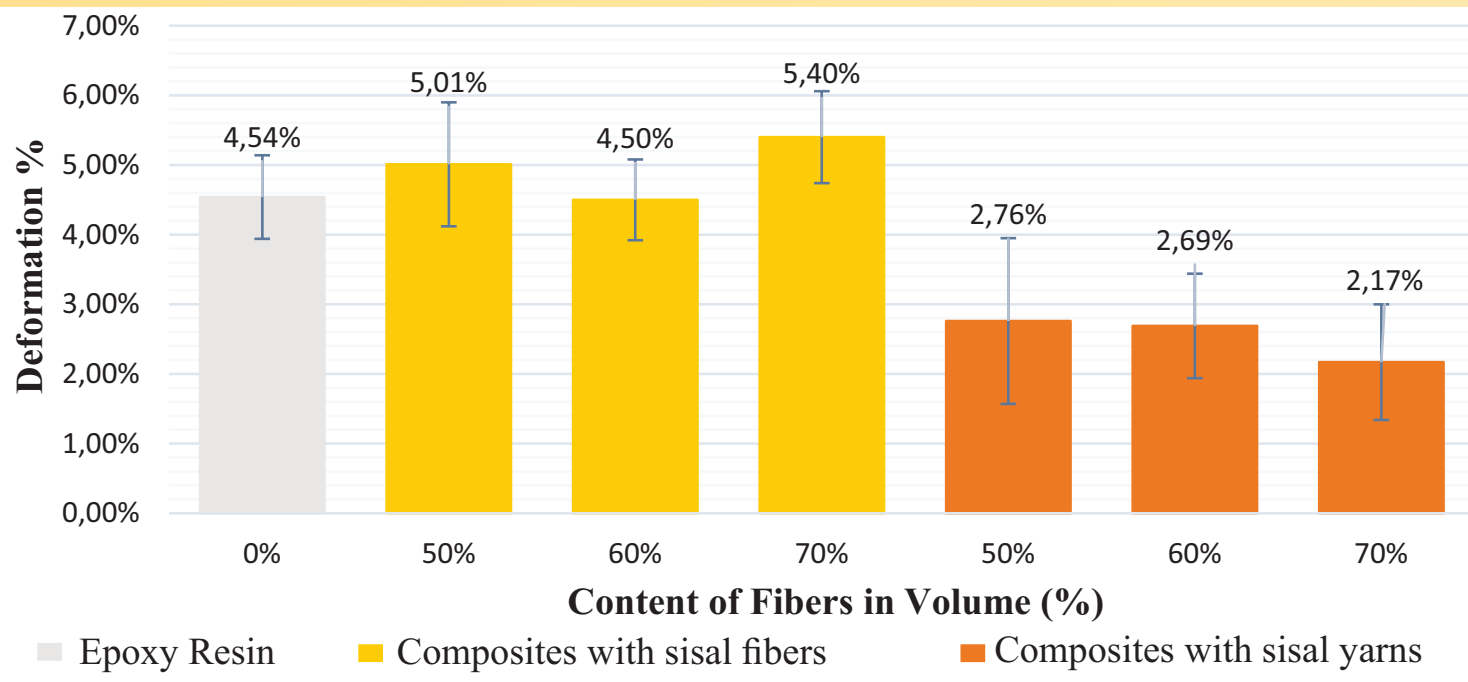

Figure 15

Maximum deformation from composites with sisal fibers and yarns

\section{Table 10}

Mechanical properties obtained in the tensile tests from CFRPr

\begin{tabular}{ccc}
\hline $\begin{array}{c}\text { Modulus of } \\
\text { elasticity } \\
\text { (GPa) }\end{array}$ & $\begin{array}{c}\text { Tensile strength } \\
\text { (MPa) }\end{array}$ & $\begin{array}{c}\text { Maximum } \\
\text { deformation } \\
\text { (\%) }\end{array}$ \\
\hline 166.82 & $2,464.48$ & 3.85 \\
$(20.11)$ & $(285.99)$ & $(0.41)$ \\
\hline
\end{tabular}

increase in the modulus of elasticity and tensile strength of composites. Except to the reinforced ones with sisal fabrics, which there had a reduction of their properties, from content of $60 \%$ to modulus of elasticity and $50 \%$ to their tensile strength and maximum deformation in the rupture (Figure 13, Figure 14 and Figure 15).

It is believed that this happened due to the sisal threads have

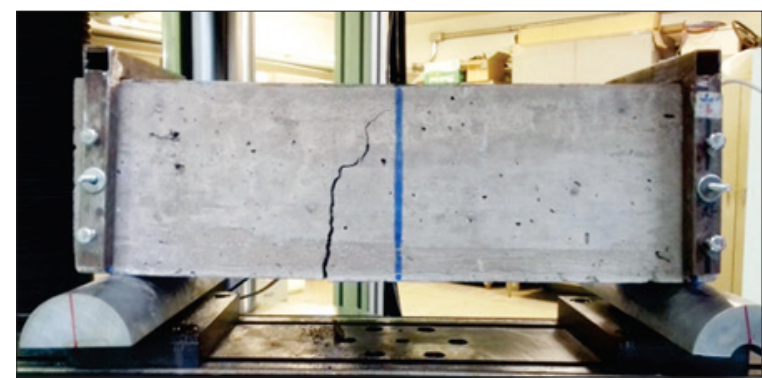

VRef-1 high diameters, with much lower specific surface compared to sisal fibers (to the same content), which resulted in the decrease of contact surface between resin and reinforcement, harming its adherence to the matrix and thus the composite performance. By the graphic in Figure 13, it is observed that the optimum content to sisal threads is $60 \%$.

So, the composite which best presented mechanical performance was the one with $70 \%$ content in sisal fibers volume, presenting maximum values obtained in the tests of $35,80 \mathrm{GPa}$ and 208,97 $\mathrm{MPa}$, to modulus of elasticity and tensile strength, respectively. Therefore, this was the composite used to tests as reinforcement to bending in reinforced concrete beams.

Comparing the results of mechanical properties from sisal composites to the results of research similar performed by Silva et al. [32], the obtained values in this study reveal a better performance. The

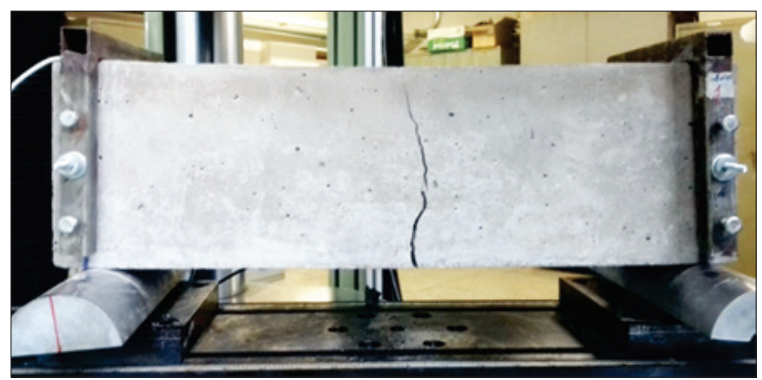

VRef-2

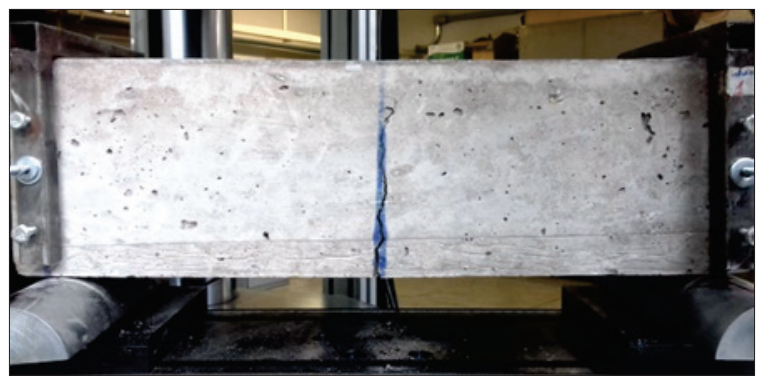

VRef-3

Figure 16

Disruption modulus from reference beams 
maximum values found by the author mentioned to the modulus of elasticity and tensile strength were of 25,59 GPa and 181,20 MPa respectively, obtained to the content of $70 \%$ in fiber volumes, being values below the obtained results in this study. The improvement of the mechanical properties occurred, mainly, by the fact of the enhancement of fiber alignment and production of composites, considering that the fibers used were themselves.

\subsection{Composites reinforced with carbon fibers}

Table 10 presents the average results obtained in the tensile tests of carbon composites. The values of standard deviation were presented in brackets. It was observed that the obtained results ratify the results informed by the manufacturer (Table 8 ).

\subsection{Analysis of the results from reinforced beams: Phase- 2}

\subsubsection{Mode of ruin in the beams}

The reference beams (Vref) presented ruptures by drainage of the rebar moved by tension without crushing of the compressed concrete, being compatible to domain 2, in which the beams were designed, according to the ones presented in Figure 16.

The beams reinforced with carbon composites presented displacement of the reinforcement previously to the rupture. This happened due to the bending and shear intermediate cracks that spread towards the reinforcement edge, causing high tangential tensions and stress in the interface, which exceeded the resistance of the
RC-1

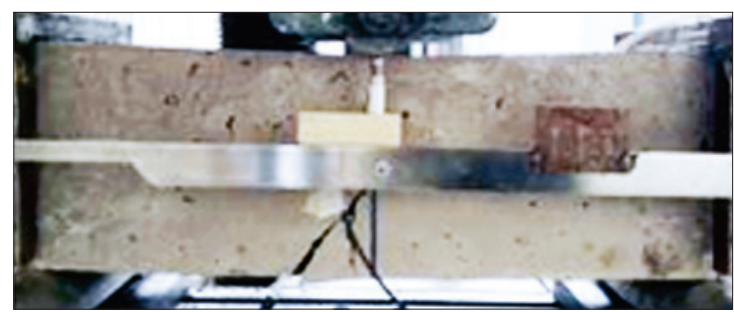

$\mathrm{RC}-2$

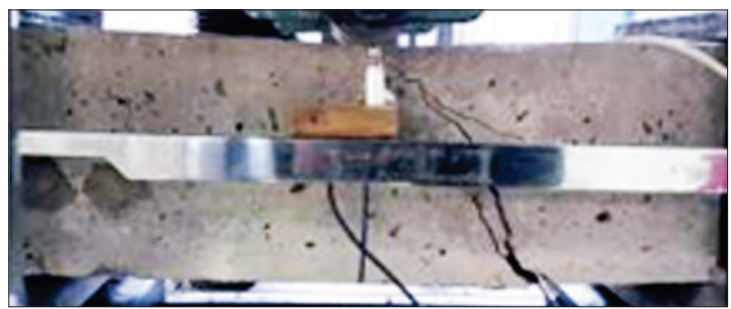

RC-3
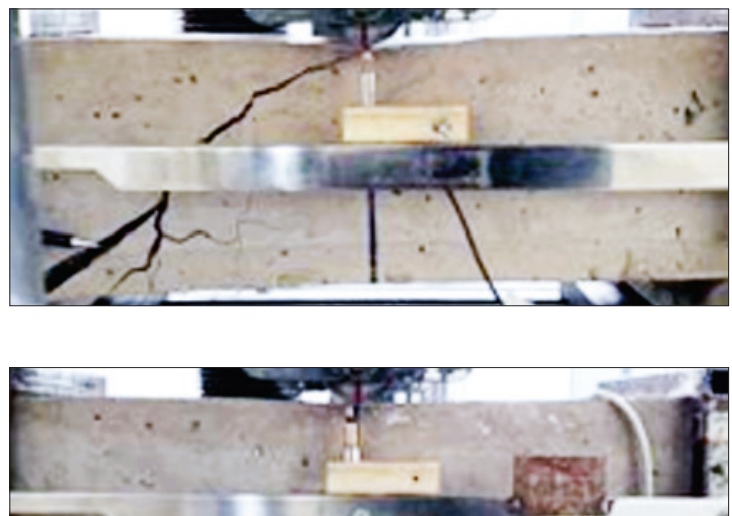

RC-4
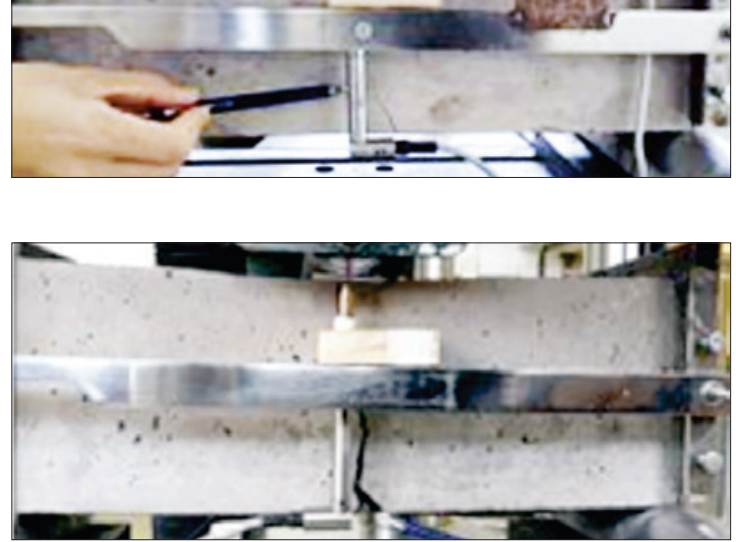
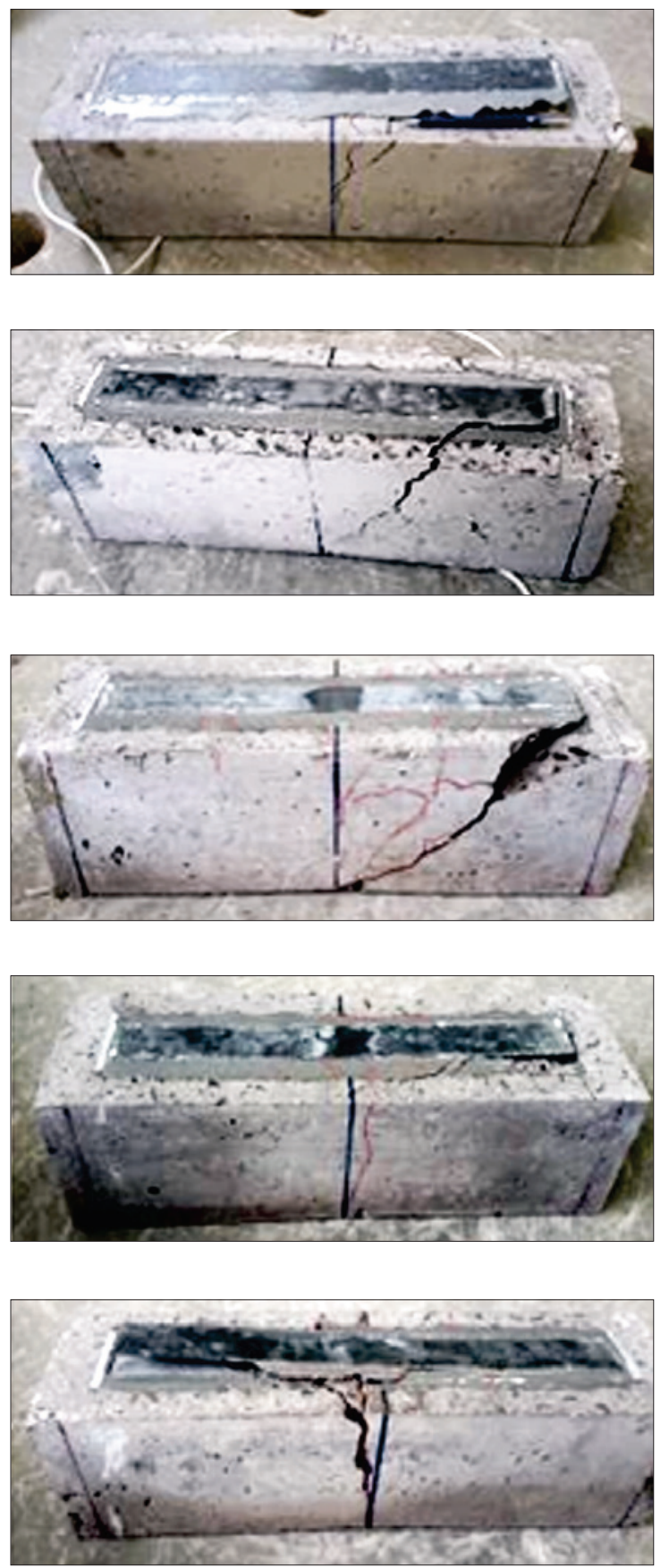

Figure 17

Disruption modulus from beams reinforced with CFRP referring RC group 
weaker element that conducted to the separation of the reinforcement of the beam. Only RC-3 beam presented a rupture by shearing, for being reached its maximum capacity to the shearing before the failure for bending. Figure 17 presents the modes of ruin in the beams from RC group.

Many studies found in literature alerted about the existence of modes in fragile ruins from the connection reinforcement-concrete in the reinforcement of beams, mainly when it is opted to use
CFRP $[4,5,33,34]$. The emergence of a fragile ruin observed in this study indicated that there was not the full use of properties tensile strength of the carbon laminate.

The tested beams from RS group, one of the beams was broken by reinforcement displacement and the rest suffered rupture in the layer of covered concrete between the rebar and the reinforcement. This happened due to high stresses in the interface that originated cracks in the end or next to the end of the reinforcement.

RS-1
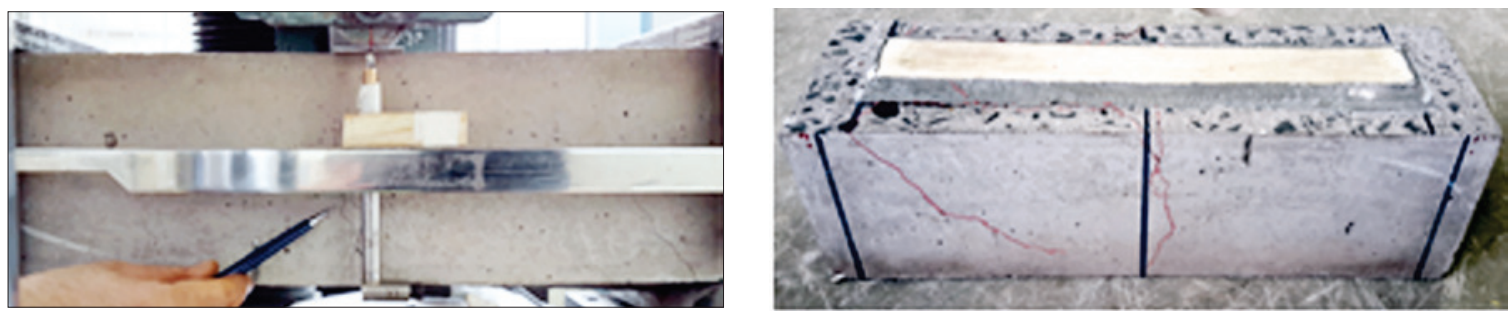

RS-2
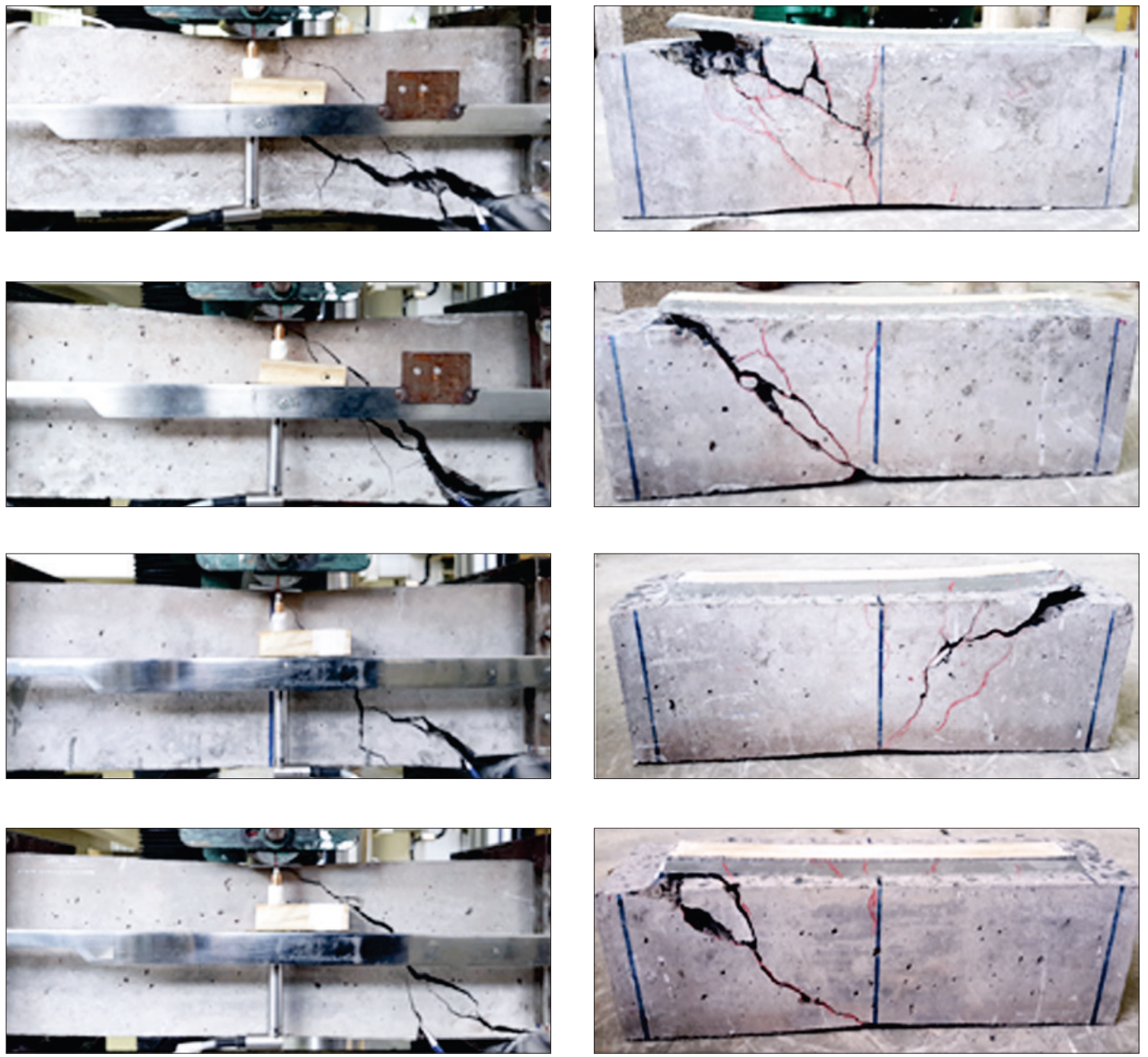

Figure 18

Disruption modulus from beams reinforced with SFRP referring RS group 
Table 11

Efforts and mode of disruption from prismatic beams

\begin{tabular}{|c|c|c|c|c|c|}
\hline \multirow{2}{*}{ Group } & \multirow{2}{*}{$\begin{array}{c}F_{f} \\
(k N)\end{array}$} & \multirow{2}{*}{$\begin{array}{c}F_{r} \\
(k N)\end{array}$} & \multirow{2}{*}{$\begin{array}{l}\text { Mode of } \\
\text { disruption }\end{array}$} & \multicolumn{2}{|c|}{ Increments (\%) } \\
\hline & & & & $F_{f}$ & $F_{r}$ \\
\hline Control & $\begin{array}{l}27.84 \\
(3.09)\end{array}$ & $\begin{array}{l}42.20 \\
(2.02)\end{array}$ & Excessive deformation of the rebar & - & - \\
\hline $\mathrm{RC}$ & $\begin{array}{l}28.92 \\
(3.94)\end{array}$ & $\begin{array}{l}64.71 \\
(6.80)\end{array}$ & Disbonding of the reinforcement & 3.88 & 53.34 \\
\hline RS & $\begin{array}{l}29.18 \\
(2.31)\end{array}$ & $\begin{array}{l}68.23 \\
(6.31)\end{array}$ & $\begin{array}{l}\text { Posting from the } \\
\text { layer of the covering of the rebar }\end{array}$ & 4.81 & 61.68 \\
\hline
\end{tabular}

These cracks spread in an inclined form until they reached the rebar level, horizontally advancing through themselves, occurring the separation of the parts between concrete and rebar. Figure 18 presents the modes of ruins in the beams of RS group.

\subsubsection{Efforts generated in the beams}

The influence of CFRP e VegFRP reinforcements from beams can be observed through the analysis of Table 11 and in the established comparisons in Figure 19. This table presents the average values of strength from first crack (Ff) and rupture of the beams $(\mathrm{Fr})$, the standard deviation values are exposed in brackets.

According to it was seen in the chart of Figure 19, it can be determined that with the presence of reinforcement to bending there had little increase in the strength of first crack. Analyzing the groups of reinforced beams, it is noted that there were similar behaviors to both types of reinforcements. The average increases verified related to beams without reinforcement were $3,88 \%$ and $4,91 \%$ to the reinforcement with CFRP and VegFRP, respectively.

The presence of the reinforcement to bending in the reinforced concrete beams have promoted a considerable increase in the rupture strength, highlighting RS group, which obtained load addition of $61,68 \%$, related to the reference beams. With the CFRP effort the increase of last load was $53,34 \%$.

Ferrari [35] performed tests similar to the present research, producing reinforced concrete beams of $15 \mathrm{~cm} \times 15 \mathrm{~cm} \times 75 \mathrm{~cm}$ dimensions and later he reinforced them with CFRP quilts, submitting

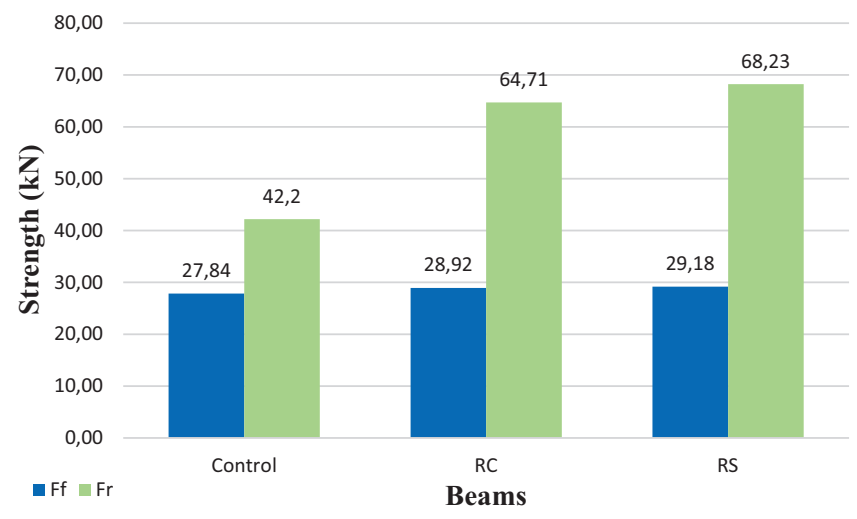

Figure 19

Comparison from disruption strengths and fissuration of the tested beams the same ones to three-point bending test. To the rupture strength of the beams, it was observed an average percentage increase related to the beams without reinforcement of $56,11 \%$, being this value close to the one obtained in this research.

Figure 20 presents the average curves experimentally obtained by strength $x$ vertical displacement, in the middle of the span, to the reinforced beams and the beams without reinforcement. It is verified that the presence of the reinforcement in the reinforced concrete beams, besides providing increase of the rupture force, it resulted in gain in the section stiffness. It is evident the increase of the beams stiffness after the appearance of the first crack in the concrete.

It is still noted that a greater extension in the end stretch of the curve from the reinforced beams with VegFRP, signaling that these reinforcement were more requested than the ones reinforced with carbon fibers. It is observed the addition of $100 \%$ in the strength after the rebar drainage to the beams with reinforcement, while to the beams without reinforcement this addition reached approximately $48 \%$.

It is still possible to observe in Figure 20 that the ascending branches from the curves regarding the beams reinforced with VegFRP, showing greater initial stiffness compared to the beams reinforced with CFRP. This can be caused due to the modulus of elasticity from the epoxy adhesive being next to the concrete and VegFRP. Thus such reinforcements have better absorbed the deformations created in the beams initially than the carbon reinforcements, in which seems to occur a kind of "slip" between the composites of high modulus and the structure, for the greater deformation of the adhesive, compared to reinforcement.

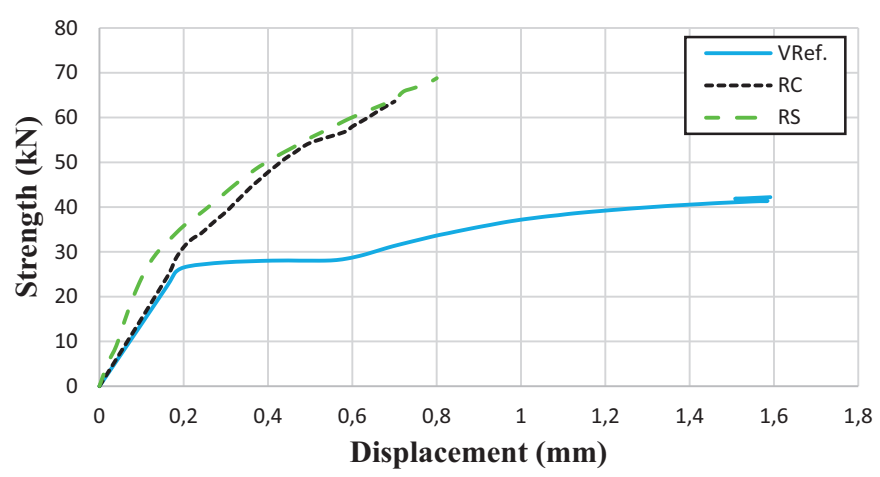

Figure 20

Strength $\mathrm{x}$ average displacement diagram, obtained to the beams of reinforced concrete reinforced to bending with CFRP and VegFRP 


\section{Table 12}

Comparative of the average arrows to loading equal $90 \%$ of disruption load from the reference beams

\begin{tabular}{ccc}
\hline Beams & Arrow $(\mathrm{mm})$ & Comparative $(\%)$ \\
\hline $\mathrm{V}_{\text {Ref. }}$ & 1.07 & 100 \\
$\mathrm{RC}$ & 0.27 & 25 \\
$\mathrm{RS}$ & 0.24 & 22 \\
\hline
\end{tabular}

A comparison between the average vertical displacements of the beams was done, in the middle of the span, when the same ones were submitted to a load equal $90 \%$ of the rupture strength, reference group (Vref). The test data in that moment are presented in Table 12. The values show that the reinforced beams, with both composites, obtained lower displacements than the reference beams, considering a same load applied, which confirms that the reinforcement was effective. Analyzing the groups of reinforced beams, it is noted that the RC beams arrows were of $25 \%$ from the VRef beams arrows. The displacement of RS beams present value corresponding to $22 \%$ of the reference beams arrows, submitted to the same load. This shows that the behavior of both reinforced beams was similar, confirming the authenticity of the results obtained by numerical simulation.

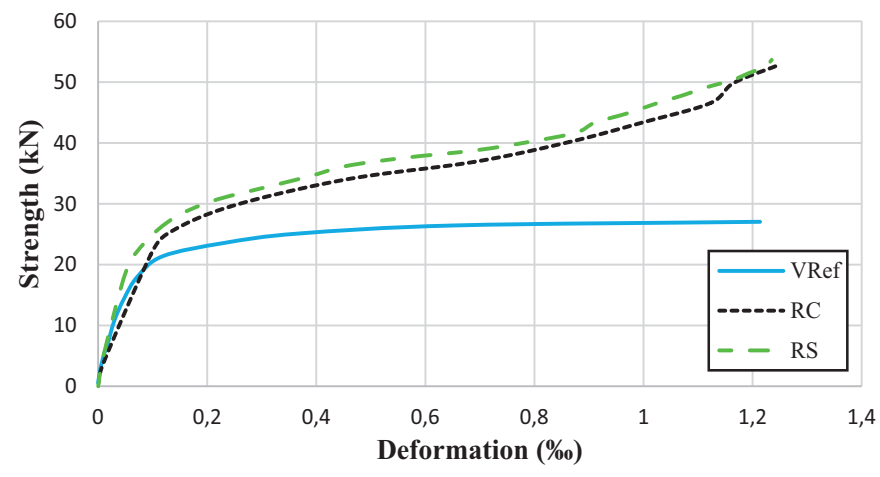

Figure 21

Strength $x$ Rebar deformation diagram, obtained to the beams of reinforced concrete reinforce to bending with CFRP and VegFRP
So, the innovation proposed in this study, which is to reinforce reinforced concrete beams to bending by gluing from these composite materials of epoxy resin with sisal fibers, is not only efficient in terms of load capacity, but also in terms of stiffness, having the advantages of being a natural material, renewable, with low cost and energy consumption to its production.

\subsubsection{Specific deformations in the rebar}

Figure 21 presents an evolution in the structural behavior of all beams, related to the strength $x$ average deformation of the longitudinal tensioned rebars. From the analysis of the diagrams, it is possible to comment the following.

It was not possible to read the deformation in the moment of the beams rupture, by the fact that cracking occurred in the region where the extensometers were located, damaging the same ones in the moments preceding the rupture.

Comparing the behavior of the reference beams to the reinforced beams, it is noted that the strengths corresponding to the deformations in the longitudinal tensioned rebars were greater in the reinforced beams than in the reference beams. This chart shows that the reinforcements absorb a part of the applied stresses, relieving the stresses in the substrate, permitting to the system to absorb greater requests.

Comparing the behavior of different reinforcements, it is noted similar performance among them, though the vegetable composites present, as a general rule, higher strengths absorbed by the structure, than the carbon composites to a given deformation in the rebar.

\subsubsection{Analysis of the influence of reinforcements on the rupture load by ANOVA}

An analysis of ANOVA-variance was performed in the obtained results in terms of rupture strength of the studied beams. In Table 13 , the statistic results obtained among all the tested series were presented.

There was evidence that the reinforcement influenced the rupture load, since F obtained was greater than Fcitrus and also P-value was lower than 0,05 . Although the tested beams were broken by shearing, stiffness from the reinforced part may have influenced in

Table 13

Analysis of the variance among $\mathrm{V}_{\text {Ref, }} \mathrm{RC}$ and RS

\begin{tabular}{ccccccc}
\hline Variance source & SQ & gl & MQ & F & P-value & F critical \\
\hline Among groups & $1,390.282$ & 2 & 695.1413 & 19.74504 & $3.3682 \mathrm{E}-04$ & 4.1028 \\
In the groups & 352.0588 & 10 & 35.20588 & - & - & - \\
Total & 1742,341 & 12 & - & - & - & - \\
\hline
\end{tabular}

$\mathrm{SQ}$ is the sum of squares of all deviations related to the average of all the observations (among and inside the samples); $\mathrm{gl}$ is the degree of liberty; $\mathrm{MQ}$ is the mean square (among and inside the samples).

$$
\mathrm{F}=\frac{\text { variance among samples }}{\text { variance inside the samples }}
$$

P-value is the probability of the null hypothesis being true. It was adopted the level of significance from 0.05 test 
Table 14

Analysis of the variance between RC and RS

\begin{tabular}{ccccccc}
\hline Variance source & SQ & gl & MQ & F & P-value & F critical \\
\hline Among groups & 30.976 & 1 & 30.976 & 0.720656 & 0.420604 & 5.317655 \\
In the groups & 343.8646 & 8 & 42.98308 & - & - & - \\
Total & 374.8406 & 9 & - & - & - & - \\
\hline
\end{tabular}

the tension distribution mechanisms, permitting the variations of the verified loads.

An analysis of ANOVA-variance was also performed to check if there was influence in the rupture load among the reinforced series. In Table 14, the obtained statistic results among the reinforced beams were presented.

It is noted that there was no significant difference among the different types of reinforcement, since $F$ obtained was lower than Fcitrus. Thus, the reinforcement with vegetable fibers composites presented similar performance to the already renowned carbon fiber composites.

\section{Conclusions}

The present study aimed to evaluate the viability in the use of VegFRP in substitution of carbon fiber composites to bending reinforcement in reinforced concrete beams, with the development of three main steps:

The first step was to obtain experimentally the elastic properties from the carbon composites $68 \%$ and sisal with contents of $50 \%$, $60 \%$ and $70 \%$, in fiber volumes, in order to analyze their behavior as structural reinforcement. To the composites with sisal fibers, it was observed that as long as the content of fibers in the composites increased, it occurred rise in the modulus of elasticity and tensile strength.

The obtained results to the composites with sisal fabrics presented additions in the modulus of elasticity until the fraction of $60 \%$, having reduction of this property to the content of $70 \%$, indicating that, to the reinforcement with this aspect ratio, the optimum content would be between $50 \%$ and $60 \%$. The drop of this result occurred by the fact that the transversal session of the wires are big, in the order of $2 \mathrm{~mm}$, lacking resin and harming the stresses transferences to the reinforcement, compromising the properties of tensile strength and modulus of elasticity to higher contents.

Among the diverse fiber contents and fabrics studied, the composite with $70 \%$ of sisal fabrics presented better mechanical performance, reporting modulus of elasticity in the order of $36 \mathrm{GPa}$, being this one used as a reinforcement in reinforced concrete beams. On the second step, a numerical analysis from the reinforced structures was made, using the computational program ANSYS ${ }^{\circledR}$, to compare the efficiency of the polymer composites of vegetable and carbon fibers, in which the vegetable composites have demanded a thickness of $5,5 \mathrm{~mm}$ to reach mechanical performance similar to CFRP. With numerical simulation, a structural analysis was made by Finite Element Method to evaluate the structure behavior under conditions of fixed requests. Specific criteria of sizing were not considered, which was not necessary in this step of the study and predimensioning of the material. Finally, it was opted to use, as a main quantification, parameter of the quantification from the behavior of the beams in ultimate limit state, which is the normal stress in the bottom and top faces of the concrete. Since the limit state of use analyzed, which is the arrow, presents few changes when it is added and when it changes the reinforcement.

The work was completed with an experimental study of the reinforced beams, comparing the effect of two types of reinforcements (carbon and sisal) in reinforced concrete beams. Analyzing the data of tested beams, the experimental results have shown that:

The composite with sisal fibers signaled to be more efficient than the reinforcement with carbon fibers, in terms of stiffness in the first moments of loading. It is believed that, with the modulus of elasticity from the epoxy adhesive close to concrete and from the vegetable reinforcement; both have contributed to better absorption of the reinforcements initially generated in the beams than the carbon reinforcements.

The influence of type of reinforcement fiber from the beams was not significant regarding load improvement, rupture and cracking modulus, once the reinforcements from the beams were designed to promote the same load improvements. The higher rupture strength between reinforced beams was to the reinforcement with sisal fibers with improvement of the load capacity of $61,68 \%$ related to the reference beams.

The rupture modulus from the reinforced beams were fragile, involving the rupture of the beams by the reinforcement deployment. The comparative analysis from the obtained results permit to conclude that the epoxy matrix composites with sisal fibers are viable to reinforce reinforced concrete structures, presenting similar performance to the renowned composites reinforced with carbon fibers (CFRP).

\section{Acknowledgements}

The authors would like to thank CAPES by the grant conferred to EMMIG-Estruturas Metálicas Minas Gerais by the supply of metallic plates to the production of the mold of vegetable reinforcement.

\section{Bibliography}

[1] DIMANDE, A. O. Influência da interface no reforço à flexão de estruturas de betão com sistemas FRP, Porto, 2003, Tese (mestrado) - Faculdade de Engenharia da Universidade do Porto, 254p.

[2] DONG, J.; WANG, Q.; GUAN, Z. Structural behaviour of RC beams with external flexural and flexural-shear strengthening by FRP sheets. Composites Part B: Engineering, v. 44, n. 1, 2013; p. 604-612.

[3] AL-AMERY, R.; AL-MAHAIDI, R. Coupled flexural-shear retrofitting of RC beams using CFRP straps. Composite Structures, v. 75, n. 1-4, 2006; p. 457-464. 
[4] FERRARI, V. J.; HANAI, J. B. Flexural strengthening of reinforced concrete beams with carbon fibers reinforced polymer (CFRP) sheet bonded to a transition layer of high performance cement-based composite. Revista IBRACON de Estruturas e Materiais, v. 5, 2012; p. 596-626.

[5] FERRARI, V. J.; PADARATZ, I. J.; LORIGGIO, D. D. Reforço à flexão em vigas de concreto armado com manta de fibra de carbono: mecanismos de incremento de ancoragem. Acta Scientiarum. Technology, v. 24, 2002; p. 1783-1791.

[6] TENG, J. G.; CHEN, J. F.; SMITH, S. T.; LAM, L. FRP: strengthened RC structures. Frontiers in Physics. 2002; p. 266.

[7] MENEGHETTI, L. C.; FILHO, L. C. P. S.; GARCEZ, M. R. Verificação da possibilidade de variação das fibras formadoras do compósito nos sistemas PRF aplicados no reforço à flexão de vigas de concreto armado. Ciência \& Engenharia, v. 16, n. $1 / 2,2007$; p. 107-114

[8] CERONI, F. Experimental performances of RC beams strengthened with FRP materials. Construction and Building Materials, v. 24, n. 9, 2010; p. 1547-1559.

[9] WENWEI, W.; GUO, L. Experimental study and analysis of $\mathrm{RC}$ beams strengthened with CFRP laminates under sustaining load. International Journal of Solids and Structures, v. 43, n. 6, 2006; p. 1372-1387.

[10] PEREIRA, P. H. F.; ROSA, M. F.; CIOFFI, M. O. H.; BENINI, K. C. C. C.; MILANESE, A. C.; VOORWALD, H. J. C.; MULINARI, D. R. Vegetal fibers in polymeric composites: a review. Polímeros, v. 25, n. 1, 2015; p. 9-22.

[11] KU, H.; WANG, H.; PATTARACHAIYAKOOP, N.; TRADA, M. Review on the tensile properties of natural fiber reinforced polymer composites. Composites Part B: Engineering. v. 42, n. 4, 2011; p. 856-873.

[12] LIMA, B. S.; PEREIRA, F. M.; LENZ, D. M.; VERNEY, J. C. K. Influência da fibra de curauá em compósitos cimentícios: verificação da resistência à flexão e da resistência à compressão. Revista de Iniciação Científica da ULBRA, v. 1, n. 9, 2011.

[13] MONTEIRO, S. N.; LOPES, F. P. D.; FERREIRA, A. S.; NASCIMENTO, D. C. O. Natural-fiber polymer-matrix composites: cheaper, tougher, and environmentally friendly. JOM Journal of the Minerals, Metals and Materials Society, v. 61, n. 1, 2009; p. 17-22

[14] SMOLE, M. S.; HRIBERNIK, S.; KLEINSCHEK, K. S.; KREŽE, T. Plant fibres for textile and technical applications. Advances in agrophysical research, v. 10, 2013; p. 52372.

[15] MATTHEWS, F. L.; RAWLINGS, R. D. Composite materials: engineering and science. Elsevier. 1999.

[16] JACOB, M.; THOMAS, S.; VARUGHESE, K. T. Novel woven sisal fabric reinforced natural rubber composites: tensile and swelling characteristics. Journal of composite materials, v. 40, n. 16, 2006; p. 1471-1485.

[17] LACERDA, M. R. B.; PASSOS, M. A. A.; RODRIGUES, J. J. V.; BARRETO, L. P. Características físicas e químicas de substratos à base de pó de coco e resíduo de sisal para produção de mudas de sabiá (Mimosa caesalpiniaefolia Benth). Revista Árvore, v. 30, 2006; p. 163-170.

[18] MOTTA, L. A. C.; AGOPYAN, V. Caracterização de fibras curtas empregadas na construção civil. Boletim técnico da
Escola Politécnica da Universidade de São Paulo, Escola Politécnica-Departamento de Engenharia de Construção Civil-USP, São Paulo, 2007.

[19] MOTTA, L. A. C.; GONÇALVES, L. K. S.; SILVA, M. R.; CUNHA, J.; DANTAS, M. E. Painéis sanduíches de poliéster reforçado com fibras de rami para aplicação na Construção Civil. Matéria (Rio de Janeiro), v. 21, 2016; p. 796-806.

[20] KAEWKUK, S.; SUTAPUN, W.; JARUKUMJORN, K. Effects of interfacial modification and fiber content on physical properties of sisal fiber/polypropylene composites. Composites Part B: Engineering, v. 45, n. 1, 2013; p. 544-549.

[21] ANTICH, P.; VÁZQUEZ, A; MONDRAGON, I.; BERNAL, C. Mechanical behavior of high impact polystyrene reinforced with short sisal fibers. Composites Part A: Applied Science and Manufacturing, v. 37, n. 1, 2006; p. 139-150.

[22] TRAGOONWICHIAN, S.; YANUMET, N.; ISHIDA, H. Effect of fiber surface modification on the mechanical properties of sisal fiber-reinforced benzoxazine/epoxy composites based on aliphatic diamine benzoxazine. Journal of applied polymer science, v. 106, n. 5, 2007; p. 2925-2935.

[23] MOHAN, T. P.; KANNY, K. Water barrier properties of nanoclay filled sisal fibre reinforced epoxy composites. Composites Part A: Applied Science and Manufacturing, v. 42, n. 4, 2011; p. 385-393.

[24] SOUSA, L. K. Produção e Caracterização Mecânica de Compósitos de Resina Poliuretana à Base de Óleo de Mamona e Fibras de Rami, Sisal e Bucha Vegetal, Uberlândia, 2013, Dissertação (Mestrado) - Universidade Federal de Uberlândia, 98 p.

[25] SOARES, I. M. Produção e caracterização de compósitos de matriz epóxi reforçada com fibra de rami para fins de reforço estrutural, Uberlândia, 2012, Dissertação (Mestrado) - Universidade Federal de Uberlândia, 98 p.

[26] AMERICAN SOCIETY FOR TESTING AND MATERIALS. Standard Test Method For Tensile Properties of Plastics. ASTM D638, Philadelphia, 2012.

[27] AMERICAN SOCIETY FOR TESTING AND MATERIALS. Standard Test Method For Tensile Properties of Polymer Matrix Composite Materials. - ASTM D3039, Philadelphia, 2014.

[28] ASSOCIAÇÃO BRASILEIRA DE NORMAS TÉCNICAS. Aço destinado a armaduras para estruturas de concreto armado. - NBR 7480, Rio de Janeiro, 2007.

[29] ASSOCIAÇÃO BRASILEIRA DE NORMAS TÉCNICAS. Concreto - Ensaios de Compressão de corpos-de-prova cilíndricos. - NBR 5739, Rio de Janeiro: 2007.

[30] ASSOCIAÇÃO BRASILEIRA DE NORMAS TÉCNICAS. Concreto - Determinação do módulo estático de elasticidade à compressão. - NBR 8522, Rio de Janeiro, 2008.

[31] ASSOCIAÇÃO BRASILEIRA DE NORMAS TÉCNICAS. Concreto - Determinação da resistência a tração na flexão de corpos de prova prismáticos. - NBR 12142, Rio de Janeiro, 2010.

[32] SILVA, A. P. O.; QUARESMA, S. C.; MOTTA, L. A. C.; FRANCKLIN, H. M. Estudo das propriedades mecânicas de compósitos de matriz epóxi reforçada com fibras de sisal para reforço de estruturas de concreto. In: $13^{\circ}$ Congresso Brasileiro de Polímeros, Natal, 2015. 
[33] FERRARI, J. V.; HANAI, J. B. Reforço à flexão de vigas de concreto armado com manta de polímero reforçado com fibras de carbono (PRFC) aderido a Substrato de transição constituído por compósito Cimentício de alto desempenho. Cadernos de Engenharia de Estruturas, São Carlos, v. 11, n. 51, 2009; p. 37-56.

[34] BEBER, A. J. Comportamento estrutural de vigas de concreto armado reforçadas com compósitos de fibra de carbono, Porto Alegre, 2003. Tese (Doutorado) - Universidade Federal do Rio Grande do Sul, 317 p.

[35] FERRARI, V. J. Reforço à flexão de vigas de concreto armado com mantas de polímero reforçado com fibras de carbono (PRFC) aderido a substrato de transição constituído por compósito cimentício de alto desempenho. São Carlos, 2007. Tese (Doutorado) - Escola de Engenharia de São Carlos, Universidade de São Paulo, 317 p. 